\title{
La nueva dimensión del Estado democrático participativo y el ejercicio de las potestades públicas en general y de la potestad reglamentaria en especial \\ The New Dimension of Participatory Democracy and the Exercise of Public Powers in General and Especially Regulatory Authority Manuel Enrique Jiménez Meza* http://dx.doi.org/10.21503/lex.v11i11.5
}

* Profesor titular de Filosofía del Derecho y Vicedecano del Doble Grado en Derecho y Ciencias Políticas, de los Estudios Combinados en Derecho y Ciencias Políticas y de Administración de la Universidad Carlos III de Madrid. 


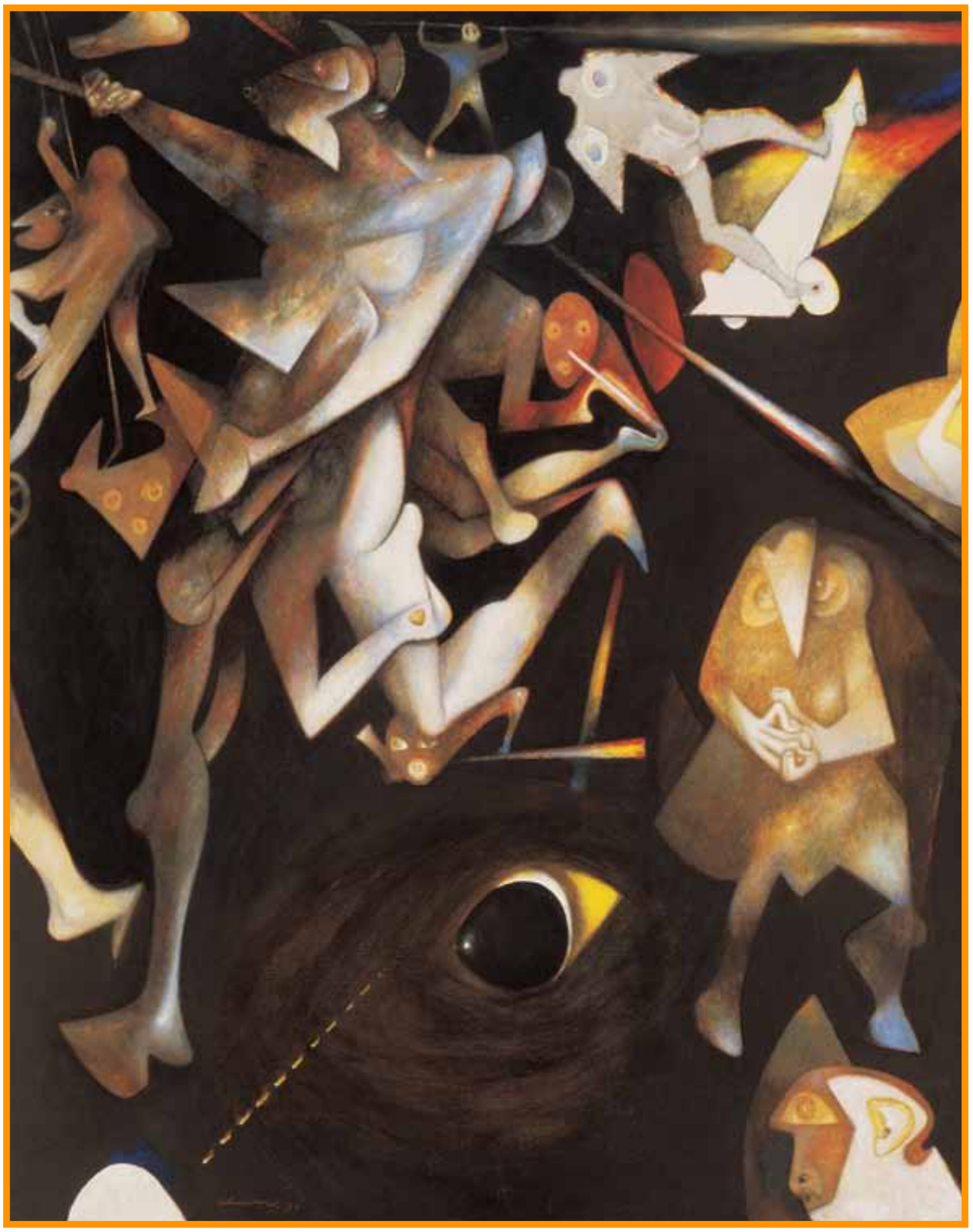

L'oeil de la terre. (1990) 


\section{RESUMEN}

"La nueva dimensión del estado democrático participativo y el ejercicio de las potestades públicas en general y de la potestad reglamentaria en especial" es un importante aporte académico que expone la nueva dimensión constitucional de la democracia, ligada al eficaz derecho ciudadano de participación en asuntos de interés público, con técnicas instrumentales para su ejecución y defensa. Ciertamente - manifiesta el autor - la "ciudadanía" es parte del nuevo eco que resuena en todo el espectro político y jurídico. Es un nuevo fantasma que ronda sobre el planeta. Para fundamentar tal aseveración, nos invita a constatar, con referencias extraídas de textos constitucionales comparados, que actualmente la democracia supone, también, la transparencia en la actuación funcionarial que apareja el principio de rendición de cuentas y el control de resultados, lo que hace suponer la coronación del Estado democrático de Derecho. Es decir, que no es tanto un mecanismo como un organismo que se hace cotidianamente tanto en la esfera individual como social, donde la libertad propia encuentra límites en la libertad ajena. La democracia es así un organismo que se vive y convive en la organización y actividad del Estado o de alguna estructura política y social, en actividades públicas, privadas o mixtas. Por ello es de suma importancia que tal organismo se proteja y vigorice con la participación ciudadana, en tanto esencia y fin de la democracia activa para la confirmación de la soberanía popular como soporte subjetivo e ideal de la soberanía que presupone la existencia del Estado constituido.

Palabras clave: democracia, ciudadanía, constitución, legitimidad, fiscalizar, derecho participativo, jurisprudencia, derecho de audiencia.

\section{ABSTRACT}

"The new dimension of participatory democracy and the exercise of public powers in general and regulatory authority especially" is an important academic contribution that exposes the new constitutional dimension of democracy, linked to effective citizen participation right in matters of public interest, with instrumental techniques for their implementation and defense. Certainly - says the author - "citizenship" is part of the new echo that resonates across the political and legal spectrum. It's a new ghost that haunts the planet. To support this idea, we are invited to verify - with references drawn from comparative constitutions articles - that democracy is now also 
transparency in administrative performance entailing the principle of accountability and results control, which suggests the ascent of the Democratic State of Law. That is, it is not so much a mechanism as an organization that is made daily in both individual and social sphere, where freedom finds itself limits on the freedom of others. Democracy is an organism that is alive and lives in the organization and activity of the State or any political and social structure, in public, private or mixed activities. It is therefore of utmost importance that the system is protected and invigorates with citizen participation, in both essence and purpose of active democracy for confirmation of popular sovereignty as subjective and ideal support sovereignty that presupposes the existence of the State constituted.

Key words: democracy, citizenship, constitution, legitimacy, prosecution, participatory democracy, jurisprudence, right of audition. 


\section{LA DIMENSIÓN PARTICIPATIVA DEL ESTADO DEMOCRÁTICO EN EL ACTUAL CONSTITUCIONALISMO COMPARADO}

\section{A. ALGUNAS CONSIDERACIONES PREVIAS DE LA DEMOCRACIA Y DE SUS ELEMENTOS CONSTITUTIVOS}

La nueva dimensión constitucional de la democracia está ligada al eficaz derecho ciudadano de participación en asuntos de interés público, con técnicas instrumentales para su ejecución y defensa, al amparo de los ordenamientos jurídicos compuestos del derecho escrito y no escrito. Queda así el ciudadano adherido al ejercicio de los derechos, por lo que es un concepto dinámico que en modo alguno se reduce a un solo ámbito del contexto social. ${ }^{1}$ Ciertamente, la "ciudadanía" es parte del nuevo eco que resuena en todo el espectro político y jurídico. ${ }^{2}$ Es un nuevo fantasma que ronda sobre el planeta, cuya manifestación multicultural quedó evidenciada en las calles del mundo contra la invasión armada en Irak en el 2003. La rebelión ciudadana -que lo digan actualmente los árabes- ha sustituido a la clásica frase de Ortega y Gasset sobre la "rebelión de las masas". La democracia supone, pues, complementariamente,

1 La clásica obra de Thomas H. Marshall. Citizenship and the Social Class. Cambridge: University Press, 1950, trazó líneas hacia el futuro en la historia de Occidente, puesto que definió al ciudadano como el estatus que ostenta, por virtud de sus derechos y deberes, como sujeto integrante de una sociedad, con trascendencia de los vaivenes del mercado y de su eventual capacidad de contribución económica, siendo así que el concepto es incondicional. Por ello, a manera de ejemplo, un ciudadano en el ejercicio de sus deberes contributivos pagaría determinados impuestos, pero los derechos políticos - y otros- no dependen de ese pago. Sin embargo, la postura de Marshall ha sido criticada con suma agudeza por David Held, quien acusa al esquema de Marshall, anclado al concepto de clase, de restrictivo. Dice: "El esquema con que Marshall y Giddens examinan la relación entre clase y ciudadanía es parcial y limitado". Del autor, vid. "Citizenship and Autonomy", en: Political Theory and the Modern State. Stanford: Stanford University Press, 1989, p. 189. En lo relativo a Giddens, quien encuentra en las luchas políticas de las clases subordinadas la esencia misma de los derechos de la ciudadanía, no deja de implicar un análisis restrictivo, el cual, aunque distinto al dado por Marshall, tienen en esto un claro punto de coincidencia analítica. De Giddens, A., vid. las siguientes obras: "Class Division, Class Conflict and Citizenship Rights", en: Profiles and Critiques in Social Theory. Londres, Macmillan, 1982, pp. 171-173, 176; también, A Contemporacy Critique of Historical Materialism. Londres: Macmillan, 1981, pp. 226-229.

2 Desde la perspectiva política como nueva modalidad histórica, vid. Heater, Dereck. Citizenship: The Civic Ideal in World History, Politics, and Education. Londres: Longman, 1990; también Vogel, Úrsula y Morán, Michael. The Frontiers of Citizenship. St. Martin's Press, 1991. 
la transparencia en la actuación funcionarial que apareja necesariamente el principio de rendición de cuentas y el control de resultados, lo que hace suponer la coronación del Estado democrático de Derecho, como pasaré a destacar. ${ }^{3}$

Bien se ha insistido en diferentes ángulos doctrinarios, que la democracia no es tanto un mecanismo como un organismo que se hace en el hacer diario desde la esfera individual hasta lo social, donde la libertad propia encuentra límites en la libertad ajena. Es así la democracia un organismo que se vive y convive en la organización y actividad del Estado o de alguna estructura política y social, en actividades públicas, privadas o mixtas. Por ello es de suma importancia que tal organismo se proteja y vigorice con la participación ciudadana, en tanto esencia y fin de la democracia activa para la confirmación de la soberanía popular como soporte subjetivo e ideal de la soberanía que presupone la existencia del Estado constituido.

Esta participación ciudadana se incardina en la denominada democracia política, sin perjuicio de la democracia económica y social. ${ }^{4}$ Incluso, en la actualidad, asistimos al arribo de las economías de mercado, ecológicas y sociales, donde el beneficio de capital se entremezcla con el desarrollo social y el equilibrio ecológico.

El ciudadano ya no es paciente sino agente de la democracia, a tal grado que podemos visualizar en las jurisprudencias constitucionales al Homo democraticus, a favor de quien se levantan, entre otros, los principios doctrinarios y jurisprudenciales del indubio pro libertate y el indubio pro homine, en caso de duda para la certera aplicación e interpretación de los derechos humanos. $\mathrm{Y}$ es esa dimensión democrática la que posibilita el amplio tejido institucional y organizacional de los Estados, con prevalencia de la razón antes que de la pasión y de la tolerancia sobre dogmas trasnochados. De lo contrario, estaríamos ante formas de Estados autoritarios o totalitarios, teniéndose para estos, desde el mismo Estado, la absorción total de la persona, sea a lo interno y externo de su comportamiento, posibilitado por el desarrollo

3 Vid. mi artículo "Nueva apertura para el ejercicio del derecho de petición y la libertad de acceso a la información pública. Notas al Voto 2120-03 de la Sala Constitucional”. Revista Ivstitia, año 17, número 195-196, marzo-abril 2003, pp. 4 a 10. El tema es de suma importancia ante la negativa del Estado para dar información precisa en relación con los supuestos beneficiarios del régimen no contributivo de pensiones por monto básico de la Caja Costarricense de Seguro Social, con resultado favorable para la pretensión invocada en la respectiva acción de amparo.

4 Dice el profesor Brewer-Carías: "Bajo esta idea democrática, por tanto, el Estado, en primer lugar, debe conformar el sistema político, para hacerlo participativo, organizando al pueblo de manera que el hombre en sociedad supere la categoría de masa, es decir, debe democratizar la democracia política. En segundo lugar, el Estado debe conformar la economía, para permitir la participación de todos en el disfrute de la riqueza, según los principios de la justicia social, y para fomentar el desarrollo de la economía al servicio del hombre, es decir, deberá hacer efectiva la democracia económica. Y, en tercer lugar, el Estado debe conformar la Sociedad, con el objeto de que, respetando y amparando la dignidad humana, no solo satisfaga las necesidades vitales y existenciales de la población, aumentando su nivel de ingreso y asegurando a todos una existencia digna y provechosa para la colectividad, sino que promueva la misma sociedad, a través de la organización del pueblo, es decir, instaurar un sistema de democracia social". Del autor, Instituciones políticas y constitucionales. Tomo I, Editorial Jurídica Venezolana, 1985, p. 179. 
de la tecnología en aras de la imposición oficial de su verdad o mentira (da lo mismo) para la sobrevivencia del sistema y de los privilegios de la casta gobernante y sus allegados. Destaquemos las características de la ideología totalitaria: ${ }^{5}$ 1) se comprende toda fase de pensamiento, acción y sentimiento humanos; 2) No se admite la tolerancia y diferencia de criterios; 3) Se simplifican en extremo los problemas y las soluciones al modo de la "raza" en el nacional socialismo o de la "clase social" en el marxismo; 4) Es fanático e impone la adhesión total, incondicional y sin reserva de los súbditos, para lo cual media el asesinato o moderna esclavización de individuos, grupos o colectividades mayores de la sociedad.

Por esto, en el totalitarismo están los súbditos o los esclavos contemporáneos al servicio del Estado y sus detentadores, no así el ciudadano como núcleo duro y expansivo de los derechos fundamentales en la democracia, ${ }^{6}$ la cual se ha visto robustecida por él y no ya por el simple administrado. Tampoco en el autoritarismo habría democracia ni ciudadanía como soporte y fin de la organización social y política. Si partimos de que en un Estado "el derecho Constitucional pasa y el Derecho Administrativo permanece", 7 en los regímenes totalitarios o autoritarios existen administrados-súbditos, a diferencia de la democracia, donde hay administrados-ciudadanos.

Haciendo un sucinto repaso histórico, los antiguos griegos caracterizaron a la democracia por tres elementos constitutivos: la isonomia, la isotimia y la isegoria. La primera está relacionada con el derecho compartido de igualdad ante la ley, la segunda con la igualdad para el ejercicio de todas las funciones, y la última con la igualdad para el derecho de expresión, sea oral o escrita. De aquí, pues, parto para elevar otro principio de la actual democracia: el derecho de participación directa o indirecta, el cual no es más que una derivación consecuente de la isegoria. Efectivamente, tal derecho de participación es prueba del exigido diálogo y de la actividad compartida entre gobernantes y gobernados, hacia el encuentro de administraciones públicas transparentes o de ventanas abiertas. Para esto, se impone la realidad: el Estado ejerce el poder a través de sus órganos y entes con apoderamiento legal y el ciudadano con sometimiento en libertad ante el Estado y por el Estado. El poder estatal y la libertad son dos dimensiones distintas, como lo son el Estado y el ciudadano, para lo que sobresale el principio de cooperación sin identidad entre ambos. Y en esta dimensión participativa intersectorial dentro de cada Estado y fuera de este para realidades interestatales, en unidades superiores

Ebenstein, William. El totalitarismo. Buenos Aires: Paidós, 1965, p. 99.

6 Con acierto se dice: "La esclavitud pasa por ser irreconciliable con el derecho del hombre a la libertad personal y, sin embargo, la civilización moderna nos ha aportado también los campos de trabajo forzado para hombres libres". Vid. Pohlenz, M., La liberté grecque. Paris, 1956, p. 7.

7 Vid. Mayer, Otto en el Prólogo de la tercera edición (29 de agosto de 1923) de su clásico Deutsches Verwaltungsrecht.1923. Lo traigo a colación simplemente para subrayar la necesaria ubicación del Derecho Administrativo más allá de cualquier dictadura o régimen militar, con ubicación adjetiva de lo dicho por el autor para la construcción de su dogmática, con trascendencia de la desaparición del imperio bismarckiano. 
para fines comunes, o a partir de los Estados para la aceptación del derecho comunitario (que en sentido estricto no es derecho nacional ni internacional, sino supranacional o de integración $)^{8}$ se hace posible la nueva dinámica del "Estado interaccional" sin imposiciones arbitrarias o de hecho. ${ }^{9}$

También el derecho de participación se hace más evidente en organizaciones internacionales con sus estructuras jurídicas y organizacionales, en las que no faltan declaraciones de derechos humanos de una u otra generación que guardan un mismo estatus de importancia.

Sin adentrarnos en el análisis riguroso y detallado del desarrollo histórico de la democracia, de lo que se ha escrito y meditado en exceso, al sumo grado de darse una conciencia universal hacia su adhesión, ha recalcado con fina ironía un autor francés: "La democracia es un régimen en el que los aristócratas han llegado a ser demasiado numerosos para ser notados y demasiado parecidos a los demás para sentirse orgullosos. Es aquel en que la élite se siente en su casa, en la calle."10

Tal humildad civil, sin ser humillación, se ha convertido en el dorado sueño de los pueblos constructores o reconstructores de libertades, por lo que podría pensarse en el renacimiento de las libertades individuales y sociales a partir de la Segunda Guerra Mundial. Por esa conciencia colectiva es que la UNESCO, en 1949, señaló en un detallado informe: "Probablemente por primera vez en la historia, la democracia ha sido señalada como la más ideal descripción de todas las organizaciones políticas y sociales por las que abogan los proponentes de más influencia." 11

Tres son, en esencia, los pilares básicos de la democracia, cuya formulación distintiva quedó consagrada por el iluminismo secular o el racionalismo individualista francés: libertad, igualdad y fraternidad, sin demérito del alcance de la Revolución norteamericana, en la que se

8 Vid. Stern, Klaus. Derecho del Estado de la República Federal Alemana. Madrid: Centro de Estudios Constitucionales, 1987, pp. 898, 899. Dice el autor: "Si las comunidades son ciertamente algo creado por los Estados, pero con propia existencia a partir de su constitución, así también el derecho por ellas establecido es igualmente autónomo en el sentido original de la palabra. No es ni derecho nacional ni derecho internacional, sino derecho supranacional, derecho de integración (Integrationsrecht) que viene a situarse junto a otras categorías, pues entre el ordenamiento nacional ciertamente existen vínculos en el momento de la creación del primero; pero con la entrada en vigor de los Tratados, estos sufren una mutación que los eleva a rango de normas fundamentales (normas constitucionales) de un ordenamiento jurídico de existencia autónoma, el derecho comunitario secundario, que trae su origen exclusivamente de aquellos. El derecho comunitario secundario tiene una nueva autoridad, otra fuente de derecho; ha tenido lugar una interpositio auctoritatis. Entre el derecho comunitario y el derecho nacional ha dejado de existir 'vínculo alguno de derivación o dependencia".

9 Vid. en tal sentido mi artículo "Perfiles del Estado moderno y la nueva dinámica del 'Estado Interaccional', en: Revista de Derecho Público. Universidad Autónoma de Centroamérica, 1996, pp. 35-51. Asimismo, en mi obra: Derecho Público. San José: Editorial Continental, 2002, pp. 63-71.

10 Delaunay. Les feuillets du temps vole. Paris, p.167.

11 Lipset, M. "Some social requisites of Democracy: Economic Development and Political Legitimacy", en: American Political Science Review. LIII, 1959, p. 71. 
gestó el expreso reconocimiento de los derechos naturales y las bases para la soberanía popular. Si los ordenamientos jurídicos carecen de aquel espíritu compuesto y complementario, que aun en tres siempre es uno, la democracia sería simple declaración semántica, sin contenido práctico-existencial. Analicemos, pues, el contexto de la libertad que presupone su pluralidad.

En la democracia, el hombre y la mujer son reconocidos como seres libres. Y la libertad compartida exige la tolerancia y, dentro de esta visión, el relativismo. Nada hay absoluto, a no ser el propio ciudadano como valor en sí mismo. Ya lo dijo mejor Kant, cuando identificó al ser humano como un fin y nunca como un medio. Pero el valor absoluto de la persona impone el respeto por el valor absoluto ajeno, en el equilibrio de los derechos y deberes compartidos. Es comprensible, pues, la famosa frase de Kelsen al caracterizar a la democracia como un "Estado de partidos"12 con imperio del relativismo político y cultural, sin que exista la superposición ideológica sino la coexistencia pacífica de perspectivas distintas. La suma de todos los absolutos, que son los seres humanos, da como resultado la relatividad de criterios. La libertad queda así unida a la pluralidad con sustento en el valor absoluto de la persona y sus derechos, incluso antes de nacer y después de morir, a partir del texto constitucional, o desde la sustancia material de los Estados constitucionales basados en la dignidad humana. Como dice Häberle: "La teoría de la Constitución es la ciencia de las Constituciones de los Estados constitucionales. Estas se apoyan sobre la dignidad humana como premisa antropológicocultural y conducen a la democracia como 'consecuencia orgánica'; constituyen una res pública con la Constitución como ordenamiento marco, que vive de que todos los ciudadanos y grupos intenten cada vez y siempre de nuevo comportarse de modo adecuado y soportarse mutuamente y que de ese modo se desarrolla". ${ }^{13}$

Por su parte, nuestra jurisprudencia constitucional ha sostenido: "Del principio de inviolabilidad de la vida se derivan varios corolarios y derechos anexos. Entre ellos cabe destacar que, como el derecho se declara a favor de todos, sin excepción -cualquier excepción o limitación destruye el contenido mismo del derecho-, debe protegerse tanto en el ser ya nacido como en el por nacer, de donde deriva la ilegitimidad del aborto o de la restitución de la pena de muerte en los países en que ya no existe. La normativa internacional, sin ser muy prolija, establece principios rectores sólidos en relación con el tema de la vida humana... No existen seres humanos de distinta categoría jurídica, todos somos personas y lo primero que nuestra personalidad jurídica reclama de los demás es el reconocimiento del derecho a la vida, sin la cual la personalidad no podría ejercerse...”. (SVC 2000-02306.)

12 Del autor: Esencia y valor de la democracia. Barcelona: Biblioteca de Iniciación Cultural, 1934, p. 37.

13 Häberle, P. Libertad, igualdad, fraternidad. 1789 como historia, actualidad y futuro del Estado constitucional. Madrid: Mínima Trotta, 1998, p. 45. 
Sin embargo, la libertad no es absoluta, toda vez que se da en el contexto de la dialéctica social, que, en sentido hegeliano y marxista, es tanto lucha como progreso. Sostiene Jaspers, desde el enfoque filosófico con alcance para la disciplina jurídico-política, que "la libertad absoluta no es una verdadera libertad, en cuanto que en ella la 'existencia' queda suprimida en favor de algo general y total, no solo desaparecen sujeto y objeto, sino que al desvanecerse todas las contraposiciones, la 'existencia' se evapora de la nada... por último, la libertad absoluta es absurda: la libertad se queda vacía donde no encuentra oposición: la libertad existe en lo contradictorio como proceso." 14

En la democracia se asume el valor absoluto de la persona, incluso antes de la formación estatal, el cual una vez constituido queda aceptado como principio irrenunciable y reforzado desde la Constitución escrita o no escrita, o desde los textos y contextos de los derechos humanos constitucionalizados, con la necesaria incorporación del conjunto de técnicas ágiles y simples para su disfrute y protección. Por ello, cualquier otro absoluto como valor o principio queda relativizado en el devenir de la democracia, por el ejercicio de la tolerancia y las libertades a través del ciudadano en confirmación de la diferencia y la oposición, en cuyo constante juego adquiere sentido el conjunto de libertades y derechos. Y todas estas libertades encuentran límites externos e internos en las personas físicas que las realizan. Condicionamientos que obedecen a leyes naturales y fisiológicas; a leyes sociales, religiosas y jurídicas, como a leyes que inciden o determinan la voluntad o motivación de cada conciencia, acción o pensamiento. También las personas jurídicas tienen sus límites, como sujetos de libertad y en libertad.

Cabe destacar aquí la pormenorizada -quizás excesiva- división conceptual de la "libertad" dada por un autor norteamericano: a) libre de (from); b) libre para (to); c) libre para (for); d) libre con (with). ${ }^{15}$ En efecto, se da la libertad "de" coerciones, lo que es la libertad negativa; está la libertad "para" actuar, expresar y concretizar los deseos; también puede suponerse la libertad "para" el cometido de fines determinados y la libertad en relación "con" los demás, para su cumplimiento. Sin embargo, la doctrina en general ha asumido una simple división que comprende la esencia de la libertad en su conjunto: la libertad negativa y la libertad positiva, es decir, la libertad de coerciones y la libertad creadora. ${ }^{16}$

14 Vid. del autor: "Filosofía". Revista de Occidente. Madrid, 1958, II, p. 45. Asimismo, Gusdorf insiste en que la libertad como principio absoluto "representa hoy una de las formas del absurdo cuya exaltación representa, desde hace más de un siglo, uno de los claros aspectos de la conciencia occidental”. Vid. La signification humaine de la liberté, París, Payot, 1962, p. 227.

15 Weiss, Paul. "Common Sense and Beyond", en: S. Hook, Determinism and Freedom in the Age of Modern Science. New York: Coliers, 1961, p. 233.

16 Bien señalan Bidart Campos y Herrendorf: "La Libertad 'de', que necesita garantizarse a todos, suele denominarse libertad negativa y debe quedar exenta de impedimentos que coarten su ejercicio y desarrollo. La libertad 'para', que necesita favorecerse en beneficio de algunos para que alcancen acceso disponible a ella, se llama libertad positiva y requiere no ya 
La democracia mantiene en su estructura el estado de transitoriedad en plena interacción cuantitativa y cualitativa con los procesos sociales de cambio. Por esto, la democracia es un valor relativo en el tiempo y en el espacio, con perfiles diferentes a través de la historia política y económica. En el siglo XIX, por ejemplo, fue interpretada en función del uso y disfrute de las libertades políticas y civiles. En el siglo XX, sin hacer renuncia de lo otro, se complementa con la requerida intervención del Estado para la protección de los derechos y libertades sociales y económicas, con espíritu benefactor hacia la gran masa de escasos o medianos recursos. Fue la entrada del Estado distribuidor y redistribuidor de la riqueza en armonía con los fundamentos del Estado interventor claramente esbozados por Keynes, aun cuando ya su dimensionamiento de concreción quedó plasmado en la obra de Bertrand de Jouvenel: Economía dirigida, publicada en 1928.

Para este siglo XXI, se impone la libertad individual y social, en el contexto de la democracia participativa con protección de los bienes ecológicos en la dimensión de los intereses colectivos y difusos, lo cual aumenta el potencial impugnatorio y fiscalizador ciudadano, con reconocimiento de técnicas procesales que hacen posible el ejercicio de la acción popular o el de la acción vecinal en el orden municipal, en lo cual el ordenamiento jurídico español resulta ser verdaderamente paradigmático. ${ }^{17}$ Es en la hora actual que se vislumbra la libertad con justicia, la participación con salud, cultura y medio ambiente protegidos; mercados desregulados en los que el Estado interviene para asegurar su libre desenvolvimiento y alcanzar economías imbuidas de lo social y ecológico. Incluso, en esta época de la posmodernidad -aun con su equívoco conceptual- asistimos a la "lucha por los derechos,"18 más allá de la lucha de clases o de cualquier interpretación determinista o reduccionista del fenómeno social, político o histórico. Los movimientos reivindicatorios y reconocedores de los distintos derechos son parte del nuevo fenómeno participativo, con incidencia global por medio del uso de la telecomunicación y la informática (telemática). La igualdad, en segundo término,

exención de impedimentos sino prestaciones concretas de dar o de hacer en favor de esos algunos que por sí solos y por sí mismos no consiguen dicho acceso por carencia de medios personales a su alcance (prestaciones de salud, de educación, de seguridad social, etc.)...”. Vid. Principios de derechos humanos y garantias. Buenos Aires: Ediar, 1991, p.176.

17 Sobre la protección de los intereses colectivos y difusos, vid, entre otros, Gordillo, A. Tratado de Derecho Administrativo. Tomo 2; La Defensa del Usuario y del Administrado, Buenos Aires: Fundación de Derecho Administrativo, 2000, cuarta edición, pp. II 1 a III 33; González Pérez. Responsabilidad Patrimonial de las Administraciones Públicas. Madrid: Editorial Civitas, 1996, pp. 159-161; Comentarios a la Ley de Régimen Jurídico de las Administraciones Públicas y Procedimiento Administrativo Común. Madrid: Editorial Civitas, 1997, pp. 575-579; Comentarios a la Ley de la Jurisdicción Contencioso Administrativa. Madrid: Editorial Civitas, tercera edición, 1999, pp. 482-484; asimismo en mis obras, con amplia referencia bibliográfica, La Legitimación Administrativa, Investigaciones Jurídicas. San José, tercera edición, 2000, pp. 387-479; Justicia Constitucional y Administrativa, Investigaciones Jurídicas. San José, segunda edición, 1999, pp. 213-244; Peña Freire, A. La garantía en el Estado Constitucional de Derecho. Madrid: Editorial Trotta, 1997, pp. 176-189.

18 En este sentido, se recomienda a Ferrajoli, Luigi. Diritto e ragione. Roma-Bari: Laterza, 1989, pp. 987-993; asimismo Zolo, Danilo. "La ciudadanía en una era postcomunista", en la revista La Política. Número 3, octubre de 1997, Barcelona: Paidós, pp. 117-131. 
como todo valor de pensamiento, tampoco ha de ser absoluta. Encuentra sentido aplicativo por la acción humana en la dialéctica social y política. La igualdad ante la ley no significa la igualación de todos los seres entre sí, sino la igualdad -como se adelantó- ante el ordenamiento jurídico y su aplicación, sin privilegios ni distinciones por su alcance erga omnes. Incluso, el famoso resabio constitucional de que nadie debe ignorar el contenido de las leyes vigentes no lo es tanto en función de una memoria privilegiada sino en razón de la aplicación igualitaria de la ley. ${ }^{19}$

Bien ha distinguido el Tribunal Constitucional español la igualdad ante la ley (vid. entre sentencias S TC 34/81 de 10 de noviembre) de la igualdad en la aplicación de la ley (vid. S TC 144/88 de 12 de julio), toda vez que la primera afecta a los acreedores de las normas, y la segunda, a los aplicadores de ella. Sutil diferencia que vincula a toda la amplia gama funcionarial pública, por lo que la norma creada adquiere vivencia propia y objetiva, incardinada en el sistema positivo y de valores normativos, cuyo espíritu y letra forman su cuerpo e identidad con efecto en los sujetos públicos, mixtos y privados.

La igualdad no debe ir en contra de la excelencia, por lo que debe aceptarse la diferencia, que es consecuencia de la libertad. La igualdad -se insiste- no es igualación. Si lo fuera, la igualdad sería un absoluto donde el sujeto y el objeto desaparecerían fugazmente por un supuesto valor ideal y metafísico alejado de la realidad práctica en pleno rompimiento con la dialéctica equilibrada de la normatividad-existencialidad. ${ }^{20}$

Por ello, en las democracias no se puede pedir que todos sean iguales en si mismos, sino solamente en la relación fáctica frente al ordenamiento jurídico. Podría haber igualdad a falta de privilegio, pues tener privilegio en la desigualdad legal es antidemocrático. Como lo sería aplicar la igualdad para casos desiguales o la desigualdad para casos iguales. Este mismo binomio clásico -aristotélico- de la igualdad, como igualdad de aplicación en igualdad de condiciones, ha sido consumada jurisprudencia de la Sala Constitucional de Costa Rica. Los seres humanos nacen y son libres e iguales no de hecho sino de derecho, siendo su motor causal el derecho natural: "Quod ad jus naturale attinet amnes homines aequales sunt" (Dig. Lib. L, Tit. XVII, ley 32).

Al respecto ha dicho nuestra jurisprudencia constitucional: "El principio de la igualdad, tal y como lo ha sido entendido por el Derecho Constitucional, hace que todos los hombres deban ser tratados igualmente por el Estado en cuanto a lo que es esencialmente igual en todos

19 Dice en lo conducente el artículo 129 de la Constitución Política de Costa Rica: "Nadie puede alegar ignorancia de la ley, salvo en los casos que la misma autorice."

20 Vid. al respecto Leibholz G. "El Tribunal Constitucional de la República Federal de Alemania y el problema de la apreciación judicial de la política”, en: REP, 1966, pp. 86 y ss. 
ellos, esto es, en los llamados derechos fundamentales que están contemplados en nuestra Constitución, que son el corolario de la dignidad humana. En cambio, deben ser tratados desigualmente en todo aquello que se vea substancialmente afectado por las diferencias que naturalmente median entre los ciudadanos". (SCV 7182-94)

Este principio universal debe aplicarse rigurosamente ante situaciones jurídicas iguales... Ha dicho esta Sala que "toda distinción que sea injustificada perdería el contenido racional de la norma jurídica y afectaría el principio de igualdad como derecho fundamental (Voto 1225-91)". Lo razonable es lo equitativo, lo correcto, lo lógico, en oposición a lo irracional, a lo incorrecto, a lo ilógico, a lo arbitrario. La equidad es la recta razón congruente con la naturaleza de las cosas (Cicerón). Es de equidad aplicar criterios distintos ante situaciones de naturaleza distinta. Con discernimiento y buena intención: "Animi judicium" (SCV 478-94)

Esa interpretación aristotélica quedó consagrada en el numeral 57 de la Constitución Política de Costa Rica: “... El salario será siempre igual para trabajo igual en idénticas condiciones de eficiencia”. En este sentido y ligando a lo anterior, dice la jurisprudencia nacional: "El principio constitucional que a trabajo igual salario igual, deriva sin lugar a dudas de un principio más amplio que es la garantía de igualdad, consistente en otorgar un trato igualitario a quienes se hallaren en una razonable igualdad de circunstancias, lo que implica que no es inconstitucional que frente a circunstancias disímiles se produzca también un trato diverso". (SCV 1725-94)

Sin embargo, tal principio sufre un revés de rigor, con una acusada contradicción lógica, aunque jurídicamente viable: “... En igualdad de condiciones deberá preferirse al trabajador costarricense" (artículo 68, ibid.), lo cual es desigualdad de aplicación aun existiendo igualdad de capacidad y de condición exigidas.

Existe otro principio regulador y fundamental de la democracia: la igualdad de oportunidades, no como si todos fuésemos iguales sino por ser precisamente desiguales. Esa igualdad de oportunidades permite, al final, parafraseando a Orwel, que unos sean más iguales que otros. Por ello, la desigualdad es una verdad funcional del sistema democrático, pero también una realidad expuesta a la crítica jurídica, política y social.

La igualdad nace como reflexión de la razón en sí misma. Ya los estoicos encontraron la igualdad por la tendencia de la razón individual unida a la razón universal. El cristianismo retomó la igualdad, pero más que por la razón lo hizo por el espíritu. Y el padre del racionalismo moderno -Descartes- dijo que la razón o el sentido común (bona mens) era la sustancia mejor repartida del mundo (en ocasiones difícil de compartir). 
También la igualdad tiende al proceso de socialización y universalización, al acercamiento entre las brechas sociales, pues una cosa son las diferencias de hecho y otras las posibilitadas por el legislador a través del Derecho. Las sociedades democráticas no deben aspirar a la homogeneidad de conciencias ni de condiciones materiales o espirituales. Deben aspirar a la justicia en la aceptación de la diferencia en el pleno goce de la libertad individual y social, donde lo formal y lo material se unen en el sujeto humano para el desarrollo de cada personalidad, con pan y espíritu. La diferencia material nunca debe ser motivo para la explotación o para la enajenación, ni la igualdad causa de la tiránica nivelación. La democracia, a través del principio de igualdad y de la participación social, debe posibilitar el denominado constitucionalismo social, para permitir la síntesis con el constitucionalismo individual. La democracia, por esto, es síntesis de la libertad y la igualdad, siendo cada una de ellas síntesis en su íntima dialéctica estructural y funcional.

Sin embargo, encontramos el conducto que permite, sin lugar a dudas, esa síntesis entre la libertad y la igualdad: la fraternidad, que respeta al ser ajeno como propio y al ser propio como ajeno. Es cuando se reconoce en el otro ser lo que el "yo" carece. Es la admisión de la libertad por el respeto ajeno y el amor por la igualdad hacia la concreción de la conciencia moral para la cooperación mutua. Es lo que posibilita que el individualismo de la libertad se fusione con el universalismo de la igualdad por el pensamiento y el sentimiento. Es, por decirlo así, el encuentro de dos mundos en principio antagónicos pero siempre conciliables.

La misma Declaración Universal de Derechos Humanos del 10 de diciembre de 1948 expresa solemnemente en su numeral primero: "Todos los seres humanos nacen libres e iguales en dignidad y derechos y dotados como están de razón y conciencia deben comportarse fraternalmente los unos con los otros ". Lo anterior con vuelta al ideario enciclopedista francés no solo por el énfasis en la racionalidad humana sino por su complemento con la fraternidad socialmente compartida, sin que tal enunciado categórico aparezca, de buenas a primeras, en la Declaración de los Derechos del Hombre y del Ciudadano del 26 de agosto de 1789.

La Constitución Política de Costa Rica exalta el principio de fraternidad a través de la "solidaridad nacional". Así, dice el artículo 74, en la dinámica del constitucionalismo social: "Los derechos y beneficios a que este Capítulo se refiere son irrenunciables. Su enumeración no excluye otros que se deriven del principio cristiano de justicia social y que indique la ley; serán aplicables por igual a todos los factores concurrentes al proceso de producción, y reglamentados en una legislación social y de trabajo, a fin de procurar una política permanente de solidaridad nacional'.

Sostiene la Sala Constitucional: "La Sala ha manifestado en reiteradas ocasiones que los derechos laborales son irrenunciables, por tanto, imprescriptibles, de conformidad con 
lo dispuesto en el artículo 74 de la Constitución Política, por lo que procede rechazar la excepción de prescripción opuesta por la autoridad accionada”. (SCV 1102-95)

"La seguridad social es un principio constitucional, a veces consagrado explícitamente (artículo 74), a veces perceptible, aunque no expreso (artículo 89). (SCV 5312-93)

"El artículo 74 cierra el mismo título invocando el 'principio cristiano de justicia social' y el equilibrio entre los factores de la producción, lo cual hace de la justicia social un valor constitucional de primer orden." (SCV 2170-93)

\section{B. LA PERSPECTIVA DE LA NUEVA CONFIGURACIÓN DEL ESTADO DEMOCRÁTICO EN EL CONSTITUCIONALISMO COMPARADO}

Analizados sintéticamente los anteriores tres parámetros (libertad, igualdad, fraternidad), daremos nuestro punto de vista para el encuentro del derecho de participación ciudadano. Reservado en esta investigación un lugar preferente a la participación ciudadana en los asuntos de interés público, realicemos algunas apreciaciones de rigor. ${ }^{21}$

El concepto "Estado de Derecho" no aparece con frecuencia sino con una marcada timidez en los textos constitucionales comparados, mas no así su realidad dogmática y orgánica. Por

21 Excelentes estudios hay sobre el tema de la participación ciudadana en la Administración Pública o en asuntos de interés público, dentro de los cuales podrían resaltarse, entre otros: Arias Senoseiain, Manuel: "La larga marcha desde la Constitución al ciudadano medio: vigencias", Foro N.100-102, enero-diciembre,1983; Alpa, G. "Aspetti e problemi della participazione nel diritto urbanistico", en: Riv. Trim.Dir.Pub. 1979, No 1; Bettini, R. La participazione amministrativa, Milán, 1973; Boulet y Roselyne, La consultation dans l' administration contemporaine. París: Editorial Cujas, 1972; Burdeau, G. "Problemi e prospettiva della participazione", en: Società civile e participazione politica. Milan: 1974; Casetta. "La participazione democratica nellordenamiento regionale", en: Foro amministrativo, 1972, V. IV. ; Chiti, M. Participazione populare e pubblica amministrazione. Pisa, 1977; Ferrier, J. P., "La participation des administrés aux décisions de Administration", en: Rev. De Droit Pub. 1974, No. 3; García de Enterría. "La participación del administrado en las funciones administrativas", en: Tomo Homenaje a S. Royo Villanova. Madrid, 1977; García de Enterría y Fernández Rodríguez Curso de Derecho Administrativo. Vol. I y II, Madrid, 1977, 1980 ; Gómez-Ferrer Morant. "Nulidad de Reglamentos y actos dictados durante su vigencia", en: Reda. No.14, julio-setiembre 1977; González Pérez. "Nuevos Sistemas de control de la Administración Pública", en Reda. No. 22 julio-setiembre 1979; González Pérez. "El proceso administrativo y la Constitución", en: Reda. No. 14, 1977; Henry-Meininger, Marie. "Vers une administration de communication : perspectives et limites des reformes engagés dans les pays occidentaux", en: Revista Internacional de Ciencias Administrativas. 2/1, 1984; Martín Rebollo, Luis. Las relaciones entre las administraciones públicas y los administrados en España: un presente para el futuro. Madrid: Instituto de Estudios Económicos, 1984; Muñoz Machado. "Las concepciones del Derecho Administrativo y la idea de participación en la administración", en: RAP. No. 84, 1977; Nieto, Alejandro. "La vocación del Derecho Administrativo en nuestro tiempo", en: RAP. No.76, 1975; Ortiz Díaz. Las nuevas bases del Derecho de Organización Administrativa. Málaga, 1971, pp. 42 y ss.; Rodríguez Vásquez de Prada, Valentín. "Nuevas perspectivas en la relación Administración Pública-Administrados", en: Documentación Administrativa. No.186, abril-junio, 1980; Sánchez Morón, Miguel. La participación del ciudadano en la Administración Pública. Madrid: Centro de Estudios Constitucionales, 1980; Sánchez Morón. "El principio de participación en la Constitución Española", en: $R A P$. No. 89, mayo-agosto, 1979; Siguán Soler. "La administración y el público", en: RAP. No. 41; Siwek- Pouydessau, Jeanne. La consultation dans la administration contemporaine. París: Edit. Cujas, 1972; Trimarchi, F. "Poteri dei dirigenti e participazione”, en: Riv. Trim. Dir. Pub. No.1, 1975; Zampetti, P. L. Società civile e participazione politica. Milán, 1974. 
ello, el término "Estado Democrático" implica el Estado de Derecho. Sin embargo, también se han dado regímenes de inspiración totalitaria que se autoproclamaron, bajo el abanderamiento constitucional, como estados democráticos. Como ejemplo de lo dicho podría citarse, entre otros, a la desaparecida "República Democrática Alemana” (antigua Constitución de 1949).

La democracia, pues, se ha transformado en el salvoconducto de la legitimidad del poder, así resuelto con insistencia a partir del fin de la Segunda Guerra Mundial. Y aun con la triste apariencia de su confirmación por distintos malabarismos de los autócratas en el poder, la democracia pasó a ser la llave maestra para abrir las puertas al entendimiento universal de los Estados, a tal grado que no falta su presencia en los distintos textos de los derechos humanos.

Las constituciones ilusorias o engañosas florecieron sin que hayan podido suplantar el gran avance de las constituciones que podríamos denominar empíricas, las cuales han empezado a imponerse en el concierto universal, cargadas de valores sociales políticamente aceptados y practicados.

El paso del dicho al hecho frente a esquemas formalistas superiores a contenidos prácticomateriales, que apenas encuentran acomodo social, están en la dimensión semiempírica, con incompleto o parcial grado de existencialidad y legitimidad.

Los Estados democráticos, en esa misma perspectiva de praxis (unidad de concepto y práctica), tienen en común un suelo y techo de inspiración humanista: el pueblo como detentador del poder y el ordenamiento jurídico como garantía de protección de los derechos y libertades fundamentales, para lo que el propio Estado queda sometido a su letra y espíritu.

El ordenamiento jurídico de valor trascendental, ubicado en el valor-persona, es el límite de actuación u omisión de las autoridades públicas, como la visible frontera entre la libertad y el libertinaje, o, si se quiere, entre el abuso de libertad contra la libertad ajena. Es la certeza de sumisión del Estado al Derecho, pero no a cualquier tipo de Derecho, sino a uno inspirado en el valor absoluto de la persona, física y jurídicamente, es decir, de contenido dikelógico o axiológico. ${ }^{22}$ Es el Estado Constitucional que da el poder y lo limita en función de los derechos humanos, siendo así que asistimos permanentemente al internamiento constitucional de tales derechos, para lo cual podríamos destacar la jurisprudencia constitucional de Costa Rica, que ha elevado por encima del texto constitucional, para su interpretación y aplicación, a

22 Las constituciones ilusorias pueden aceptar en apariencia la carga ideológica del Estado de Derecho. Por ello, en el análisis de la igualdad ante la ley, se ha dicho, sintetizándose diferentes posturas: "2) Todo el mundo está protegido (igualmente) por algún conjunto de normas jurídicas imparcialmente aplicado, sin temor, favoritismo o similar por un poder judicial independiente. En este sentido, Sudáfrica y Rodesia (fueron) Estados de Derecho, aunque parte del derecho en cuestión sea abominable en su contenido" (paréntesis y contenido de adaptación nuestro). Marshall, Geoffrey. Teoría Constitucional. Madrid: Espasa Calpe, 1982, p.181. Ello implica-decimos- la sujeción a un Derecho sin contenido humanista y antidemocrático, sin que la comprobación empírica del Estado de Derecho sea una realidad. A lo sumo asistimos a la presencia de otro estado moderno con Derecho, pero no así de Derecho. 
las distintas proclamas de derechos humanos. Esto trae a la memoria la Constitución de Suiza, que otorga rango constitucional a la Convención Europea de Derechos Humanos. Se debe resaltar también al Tribunal de Justicia de Luxemburgo, que ha puesto a los derechos humanos como principios generales del Derecho.

Así, entonces, en las democracias existe toda una amplia gama de derechos y libertades que están presente en los apartados dogmáticos de las Constituciones escritas y en la configuración jurídica escrita y no escrita del Derecho del Estado Constitucional, que hace la Constitución no escrita. Y, asimismo, hay celosas defensas instrumentales e institucionales para su protección, uso y disfrute. Y ello queda relacionado con las partes orgánicas de las Constituciones Políticas que distribuyen el poder del Estado, que aun siendo uno prolifera en múltiples átomos jurídico-políticos. La amplia constelación de entes y órganos fundamentales o de rango constitucional con derivación en el ámbito administrativo quedan en principio equilibrados en la ecuación del peso y contrapeso democráticos.

Así, pues, uno de los componentes materiales del Estado actual, amén de otros, es el ordenamiento jurídico-constitucional, del cual se derivan otros ordenamientos de rango inferior, en la tesitura kelseniana de la estructura decreciente normativa en función intercalada e interrelacionada. Sin embargo, a pesar de lo indicado, también es cierto que el positivismo llevado a extremos oportunistas, con traición de sus fundamentos científicos, ha constituido válvula de escape para políticas oprobiosas contra la humanidad que, luego del ayuno que hizo sacar a flote su mala conciencia, elevó como premisas universales a las Declaraciones de derechos humanos. Fue la vuelta al iusnaturalismo con sus propias variantes, para dar aplicación de vida a valores humanitarios sin que la norma valga por sí misma, como si fuese un producto in vitro, de química pura, o la consecuencia de una elaboración lógica o matemática del pensamiento. Simplemente se dejó en claro que el Derecho por sí mismo no es puro, como nunca lo es alguna ciencia social, intrínsecamente compleja y combinada de elementos y factores normativos, como supranormativos o intranormativos, sin que por esto la ciencia jurídica deje de ser ciencia, sino que se constituye en una ciencia distinta a la ciencia exacta -ni tienen por qué ser iguales-, con su propio método y objeto de estudio. Aceptar el Derecho como Derecho y no ya como simple Ley positiva es un problema para el riguroso positivista y para la construcción de axiomas fundadores de edificaciones cuyas hipótesis iniciales, si resultan cuestionadas o invalidadas, harán inválidos también los sistemas en su conjunto. Por ello, la ciencia jurídica, aun siendo ciencia social, no por esto deja de ser ciencia, como la ciencia no deja de ser social. ${ }^{23}$

23 Incluso en la actualidad existen corrientes científicas que cuestionan la pureza de la denominada ciencia exacta o empírica. Puede escucharse la airada voz de NAES en: “¿Por qué no ciencia también para anarquistas?”. Cuadernos Teorema. No. 53, Valencia 1979, pp. 55-57, donde reclama que la ciencia no le dice la verdad al poder, sino que se trasforma en su instrumento para la creación de nuevos y terribles ingenios bélicos y antiecológicos. Asimismo, enumera sus críticas, las cuales podrían sintetizarse así: a) La ciencia moderna no es políticamente neutral; b) Los científicos no atacan su 
Toda escogencia implica valoración: tanto el positivista como el iusnaturalista toman para sí sistemas de valores, sin que haya neutralidad axiológica tan acusada para la ciencia exacta, empírica o analítica. Lo llamado metajurídico, pues, en relación con la sustancia jurídica, ya no queda en la dimensión de lo meta sino que se le adhiere, en tanto manifestación social, todo un conjunto de elementos históricos, sociológicos, políticos, económicos, filosóficos, e incluso el derecho no escrito, que incluye a la costumbre y a los principios generales del Derecho, razón por la cual el ordenamiento jurídico trasciende e incorpora a la norma positiva. En efecto, el término "Derecho" es más amplio que el de "Ley", lo cual fue claramente puntualizado por el entonces Tribunal Constitucional de Alemania Federal para definir el alcance, en apariencia contradictorio, de los numerales 20,3 y 97,1 de la Ley Fundamental de Bonn (Constitución de Alemania Federal).

Sobre la discusión de que los jueces quedaban sujetos a la "Ley y al Derecho" (artículo 20) o solamente a la "Ley" (artículo 97), la doctrina y la jurisprudencia se inclinaron por la concepción compuesta de la "Ley y Derecho" equivalente a ordenamiento jurídico, más amplio y abarcador que la letra positiva de la Ley. ${ }^{24}$

Es así entonces que en tiempos históricos diversos y con sus propias modalidades circunstanciales, salen a la luz diversos textos constitucionales que de una u otra forma plasman a la democracia como sistema de organización y actividad estatal y social. Entre ellas, a manera de ejemplo, cabría citar a las constituciones de Alemania, Italia, Francia y

propia posición de privilegio; c) Los científicos apoyan la ingeniería social irresponsable; d) Hay crueldad para con los animales y los hombres, carencia de respeto a la dignidad personal; e) No es cierto que la ciencia por su propia naturaleza apoya la democracia y la libertad; f) Es falsa la enseñanza de que la ciencia no requiere de filosofía o metafísica, toda vez que encierra en sí misma una base intelectual indiscutible; g) La llamada racionalidad científica en la mayoría de las veces es una absurda confianza en el intelecto, en detrimento del espíritu; h) "La ciencia es, por su propia metodología, apta para apoyar el "reduccionismo" y el positivismo, para destruir lo maravilloso..."; i) Tiende la ciencia a favorecer el distanciamiento entre el hombre y la naturaleza. La crítica de NAES no es tanto una crítica a la ciencia como al científico. Y es, a su vez, una visión tan reduccionista como el mismo reduccionismo criticado. Sin embargo, creemos, toca factores relacionados, con suma sinceridad, con nuestra "civilización tecnócrata". El propio BUNGE dice que la ciencia es un sistema de valores y fuente de valores. Vid. Ética y ciencia. Buenos Aires: Editorial Siglo Veinte, 1972. O cuando Popper indica que la "objetividad científica" y la "neutralidad valorativa" son ya los valores y no neutralidad. Vid. La lógica de las ciencias sociales. Barcelona: Grijalbo, 1973, p. 112. Tampoco hay neutralidad en la ciencia, toda vez que la actividad científica se desarrolla sobre sistemas de valores, como son la verdad, el progreso, etc. Pretender tal neutralidad es decir que la ciencia no tiene relación social y es eminentemente abstracta, lo que no es cierto. Vid. del autor: Ideología y ciencia. Valencia: Fernando Torres Editor, 1976, pp.135-136. Para Kuhn, T., todo cambio científico es un proceso históricopsicológico -sociológico, dinámico, realmente complejo. Vid. The Structure of Scientific Revolutions. Chicago, 1970. Lo anterior en relación con la teoría paradigmática, sin que la misma tenga un sentido unívoco y simple. En tal perspectiva, vid. Masterman. "The Nature of a Paradigm", en: Criticism and the Growth of Knowledge. Cambridge: University Press, 1974, pp. 59-89.

24 Esa misma dimensión englobadora de "ordenamiento jurídico" queda consagrada en los numerales 7 y 8 de la Ley General de la Administración Pública de Costa Rica, donde las normas no escritas -costumbre, jurisprudencia y principios generales del Derecho- son parte integrante del ordenamiento jurídico administrativo, donde, a su vez, la normativa no escrita servirá para complementar, en su texto, el ordenamiento escrito en caso de suplencia, no así por insuficiencia de la ley escrita. 
España, y en América Latina, a las de Argentina, Brasil, Colombia, Costa Rica, Paraguay, Perú y Ecuador.

Dice al texto el numeral 20,1 de la Constitución de Alemania Federal: "La República Federal de Alemania es un Estado federal, democrático y social". Sin que exista en la actualidad la división de Alemania, se consagró para ella la fórmula "Estado democrático" que supone el Estado de Derecho, sin que sea a la inversa, con énfasis primigenio y originario en la forma política y social democrática. Y ello podría tener una explicación histórica. En efecto, también el Tercer Reich se abanderó como "Estado de Derecho", para lo que sirvió en parte el material elaborado por Carl Schmitt, en estricta referencia a la unidad del Estado y el Derecho -su innovado Derecho-, con divorcio de los altruistas valores democráticos. ${ }^{25}$ No hay duda de que para la nueva Alemania su sistema político queda regulado por los parámetros democráticos en la visión comprensiva que va desde la estructura del Estado en y para la libertad, hasta el derecho participativo del ciudadano con su zona jurídicamente protegida.

También la Constitución de Italia en su artículo 1 dice: "Italia es una República democrática basada en el trabajo". Ha sostenido un distinguido autor: “... bien puede decirse que la noción de "estado democrático" comprende hoy una extensa gama de soluciones, todas ellas caracterizadas por el reconocimiento, al menos teórico, de que corresponde al pueblo, es decir, a la generalidad de los ciudadanos considerados colectiva e igualitariamente, la competencia para adoptar las decisiones esenciales para la vida de la comunidad." ${ }^{26}$ Asimismo, la fórmula del constituyente italiano fue la de "república democrática" que da por cierto y obtenido el Estado de Derecho, tanto a través del sistema republicano (cuya puntualización moderna fue anticipada por Maquiavelo y Montesquieu, con retomo de la res publica romana), como por la organización política democrática. Empero, quedó incorporado el derecho de participación popular para la eventual toma de decisiones políticas y jurídicas, lo que es posible por medio del referéndum popular (artículo 75) para otorgar la aprobación total o parcial de una ley o de un acto con valor de ley, según sea requerido por lo menos por quinientos mil electores o por cinco Consejos regionales.

Reza la Constitución de Francia en su artículo 2: "Francia es una República indivisible, laica, democrática y social”. Permanece, pues, el sentimiento republicano (la Quinta República), propio de la concepción moderna del Estado que da por incluido al Estado de Derecho.

25 Schmitt, Carl. "Der Rechtsstaat", en: Nationalsocialistisches Handbuch für Recht und Gesetzgebung. Editado por el Dr. Hans Frank, München, 1935, pp. 3-10. También vid. mi estudio, con amplia referencia bibliográfica: "Legalidad y legitimidad del Estado constitucional”, en: La Sala Constitucional. Homenaje en su X Aniversario. 1999, pp. 172-176. Asimismo Gómez Orfanel, G. Excepción y normalidad en el pensamiento de Carl Schmitt. Madrid: Centro de Estudios Constitucionales, 1986, pp. 251-272.

26 Pizzorusso, Alessandro. Lecciones de Derecho Constitucional. Madrid: Centro de Estudios Constitucionales, 1984, T.I, p. 23. También Crosa E. "IL fattore politico e la constituzione”, en: Scritti in onore di Raneletti, Padua. 1931, pp. 148 y ss. 
En América Latina existe semejante lineamiento constitucional europeo en favor del Estado social y democrático de Derecho. Así, la Constitución de Colombia dice en su artículo 1: "Colombia es un Estado social de derecho, organizado en forma de república unitaria, descentralizada, con autonomía de sus entidades territoriales, democrática, participativa y pluralista...". Señala la Constitución del Paraguay en su artículo 1: "La República del Paraguay es para siempre libre e independiente. Se constituye en Estado social de derecho... La República del Paraguay adopta para su gobierno la democracia representativa...”.

El artículo 1 de la Constitución de la República Federativa de Brasil dispone: "La República Federativa de Brasil, formada por la unidad indisoluble de los Estados y Municipios y del Distrito Federal, se constituye en Estado Democrático de Derecho y tiene como fundamentos: ...IV los valores sociales del trabajo y de libre iniciativa...”.

La Constitución del Perú en su artículo 43 dice: "La República del Perú es democrática, social, independiente y soberana...”. Por su parte, la Constitución de Argentina, con su profunda reforma parcial de 1994, si bien no proclama al Estado como democrático, social y de Derecho, su contenido dogmático no deja de evidenciar la presencia de las libertades individuales, los derechos sociales y la participación ciudadana en la toma de decisiones políticas fundamentales, tales como la iniciativa popular en la presentación de proyectos de ley al Parlamento, con exclusión de reformas constitucionales, tratados internacionales, tributos, presupuesto y materia penal (artículo 39); la consulta popular vinculante con rango de promulgación automática en caso de voto afirmativo; así como la consulta popular no vinculante (artículo 40). Por su parte, el artículo 1 de la Constitución de la República del Ecuador (2008) enfatiza: "El Ecuador es un Estado constitucional de Derecho y justicia social, democrático, soberano, independiente, unitario, intercultural, plurinacional y laico. Se organiza en forma de república y se gobierna de manera descentralizada."

La Constitución de Costa Rica en su numeral 1 sostiene: "Costa Rica es una República Democrática, libre e independiente". El Estado de Derecho queda, pues, esbozado por la misma fórmula de "República democrática", que a su vez, creemos, sobrepasa los límites clásicos del Estado de Derecho para incorporarse en la dinámica moderna de la participación popular o ciudadana. En análoga situación se perfila la Constitución francesa.

Si tomamos ahora la Constitución Política de Polonia (1997), en representación de la modalidad estatal exmarxista, bajo el otrora dominio militar y logístico de la ex Unión Soviética, resulta halagadora la lectura -amén de todo el texto-del artículo 2: "La República de Polonia es un Estado democrático de derecho con ejercicio de los principios de la justicia social". 
Tal vez la más explícita de las anteriores constituciones sea la de España (artículo 1.1): "España se constituye en un Estado social y democrático de Derecho, que propugna como valores superiores de su ordenamiento jurídico la libertad, la justicia, la igualdad y el pluralismo político". Sin duda alguna, la Constitución de España mantiene una definición que sintetiza excelsamente la inquietud del actual constitucionalismo: el Estado social, democrático y de Derecho. Sin embargo, también es cierto que la Constitución de España enumera inicialmente el Estado social, y luego el democrático, lo que le ha valido cierta critica de la doctrina doméstica. En efecto, dice un autor en sus comentarios a la Constitución: "Creemos que la inversión no es correcta, debiendo ir en primer término la palabra 'democrático'. Un Estado puede tener un carácter eminentemente 'social' y no ser democrático, al menos en las definiciones constitucionales, y ello acontece frecuentemente con los sistemas autoritarios". ${ }^{27}$

Ahora bien, creemos que con la inclusión expresa del Estado democrático, aun siendo posterior al Estado social, no se invalida ni desnaturaliza el contexto global e irrenunciable de esa aparente dicotomía cuya solución se funde en la unidad constitucional. El orden no altera el producto y menos aun cuando deviene de una nítida norma cuya primacía originaria es incuestionable. Y en la unidad del texto constitucional tal trilogía del Estado democrático, social y de Derecho encuentra claro acomodo complementario sin exclusión ni contradicción entre sí.

En todos los textos citados la democracia ocupa un lugar preferente y esencial como ratio constitucional. Y ella queda incardinada al imperio de la ley como expresión de la voluntad popular y a la participación ciudadana en los asuntos de interés público. La dimensión democrática del Estado constitucional permite acercar dos ángulos extremos: el Estado y la sociedad, sin que la sociedad sacrifique al Estado ni el Estado a la sociedad. Debe ser la garantía para la efectiva integración - no confusión- de la sociedad en el Estado y por el Estado, en pleno goce del ejercicio soberano de su autorregulación normativa, en estrecha relación con la voluntad popular mayoritaria y con respeto de la voluntad minoritaria, ambas como expresión legítima de la libertad. Así, entonces, el Estado democrático es un Estado "societario" integrado a la sociedad y esta con el Estado.

27 Belmonte, José. La Constitución. Texto y contexto. Editorial Prensa Española, 1979, p. 67. También existe otra crítica a la norma transcrita del artículo 1 de esa Constitución, la cual ya fue expuesta en el Senado de ese país por el profesor Ollero Gómez: "La frase "España se constituye..." solo tiene sentido si nos situamos en un momento previo a la aprobación y promulgación del texto constitucional, pero a partir del día en que la Constitución entre en vigor, España deja de constituirse para quedar constituida en la forma que la Constitución prescribe. Por consiguiente, propuso que la citada frase se sustituyese por "España es...". No se aceptó su enmienda, pero hay que reconocer que no le faltaron razones". Vid el análisis de Garrido Falla en: Comentarios a la Constitución. Editorial Civitas, 1985, T.I, p. 24. 
Tal Estado imbuido de la participación ciudadana, en diálogo y acción, no se consume simplemente en la dimensión social del Estado benefactor. Es esto y todavía más, pues el Estado societario tiene relación directa y sustancial con la democracia participativa, sin que se agote en las políticas económicas y jurídicas de acercamiento entre las distintas esferas sociales. Ha señalado con precisión E. Forsthoff: "El Estado liberal de Derecho es un Estado que garantiza la subsistencia y, por lo tanto, es Estado de prestaciones y de redistribución de riqueza." ${ }^{28}$

La democracia queda pues identificada con el Estrado constitucional, y así debemos asistir a la participación en libertad y en proyección de apertura constante, donde los dados nunca están tirados de antemano ni el futuro preconcebido, a falta de disposiciones esotéricas, y sin brujos ni hechiceros postrados en una simple concepción que pasa a ocupar el sacrosanto nivel de la verdad (mentira) oficial. De lo contrario, el dogma estaría sobre la razón, la imposición sobre la participación y la autoridad sobre la libertad.

\section{EL DERECHO CONSTITUCIONAL DE PARTICIPACIÓN CIUDADANA} Y SU ENCUADRAMIENTO EN LA LEY GENERAL DE LA ADMINISTRACIÓN PÚBLICA

\section{A. EL DERECHO DE PARTICIPACIÓN ÍNSITO EN EL TEXTO DE LA CONSTITUCIÓN POLÍTICA}

La Constitución de Costa Rica tiene algunos principios de participación ciudadana, con lo cual aumenta el espíritu proyectivo de su Preámbulo, que exalta la "fe en la democracia ", como la carga ideológica del artículo primero: "República democrática...”.

Existen muchas formas de participación ciudadana, desde la participación activa en un colegio profesional como ente público no estatal hasta el derecho-deber ciudadano en las elecciones populares. De esa manera encontramos diversos numerales que garantizan tal participación. Así, el artículo 9 define al gobierno dela República como” popular, representativo, alternativo y responsable" en relación con la categoría cualificada de "ciudadano ", que es el costarricense mayor de edad que puede ejercitar "el conjunto de derechos y deberes políticos" (artículo 90), salvo por el régimen excepcional de interdicción o por sentencia penal dictada al efecto (artículo 91). El sufragio como actividad política constitucionalmente garantizada es una "función cívica primordial y obligatoria", ejercitada por los ciudadanos inscritos en el Registro Civil ante las Juntas Electorales (artículo.93). Compete al Tribunal Supremo de Elecciones, que mantiene el rango de un Poder del Estado (artículo 9), convocar a elecciones populares y ejercitar todas las técnicas formales y materiales para que los "procesos electorales se

28 Del autor, "Problemas constitucionales del Estado social", en: El Estado social. Madrid: Centro de Estudios Constitucionales, 1986, p. 49. 
desarrollen en condiciones de garantías y libertad irrestrictas" (artículo 102). Cada cuatro años (artículo 134) se eligen los representantes del Poder Ejecutivo como órgano constitucional, los diputados de la Asamblea Legislativa, electos por provincias (artículo 106), y los regidores municipales para la formación de esos Gobiernos locales (artículo.169).

Ahora bien, la reforma parcial de mayor trascendencia aparente que ha sufrido la Constitución de Costa Rica fue la Ley publicada en el diario oficial La Gaceta de 20 de junio de 2002, cuyo texto dice: "Transitorio único de ley 8281 de 2002 -las leyes especiales referidas en los artículos 105 y 123 de la Constitución Política, aquí reformados, deberán dictarse dentro del año siguiente a la publicación de esta ley. Durante este plazo, no entrará en vigor lo aquí dispuesto". Sin embargo, para burla de la ciudadanía y de la buena fe democrática, el año se cumplió el 20 de junio de 2003, sin que el Parlamento la dictara en el plazo designado para hacer eficaz el referéndum y la iniciativa popular para la formación de las leyes. Posteriormente, la Ley sobre Regulación del Referéndum salió publicada en el diario oficial La Gaceta número 67 de 4 de abril de 2006

En todo caso, desde el texto constitucional, existen contrasentidos y vacíos jurídicos de tratamiento positivo que hacen de la reforma constitucional un salto más formal que material, en perjuicio de la eficacia democrática. En efecto, el artículo 105 otorga al cuerpo electoral debidamente inscrito, en un porcentaje al menos del 5\%, para que pueda ejercitar el referéndum con potestad para aprobar o derogar leyes y reformas parciales de la Constitución Política. Empero, y aquí viene un primer ángulo crítico, según lo dispone el artículo 102 ibid., no podrá haber más de una convocatoria de referéndum por año, lo que no deja de ser restrictivo, sobre todo si se suma la prohibición de hacerlo a los seis meses anteriores y seis meses posteriores de la elección presidencial. Existe además una verdadera burla a la ciudadanía cuando se exige al menos, para que el resultado sea vinculante, la participación de un $30 \%$ de los ciudadanos inscritos en el padrón electoral para la legislación ordinaria y de un $40 \%$-también al menos- para las reformas parciales de la Constitución y para los asuntos que requieran de la mayoría calificada para la aprobación legislativa. En otros términos, el mínimo del $5 \%$ sólo es para la convocatoria, sin que el resultado sea vinculante para el Estado a no ser que se logre el $30 \%$ y el $40 \%$ respectivamente del padrón electoral. Sin duda alguna con esto se da una verdadera desproporcionalidad de porcentajes, siendo así que en porcentajes menores al $30 \%$ y $40 \%$ para los supuestos indicados, el resultado de la consulta popular no pasaría de ser una formalidad de posibles efectos morales o políticos, pero no así imperativamente jurídicos, que al final es lo que interesa.

De otra parte, la reforma del artículo 123 ibid. dispone el reconocimiento para la iniciativa popular en la formación de las leyes en tanto se cumpla con el mínimo del $5 \%$ del padrón electoral debidamente inscrito. Asimismo, se prohíbe la iniciativa popular en las siguientes 
materias: presupuestaria, tributaria, fiscal, aprobación de empréstitos y contratos o actos de naturaleza administrativa. Esta limitación a su vez es menor frente a la limitación para el referéndum, en el cual no se puede consultar lo siguiente: materia presupuestaria, tributaria, fiscal, monetaria, crediticia, pensiones, seguridad, aprobación de empréstitos y contratos o actos de naturaleza administrativa. Por consiguiente, encontramos disparidad evidente en lo que respecta a lo monetario, crediticio, pensiones y seguridad. Surge de inmediato una duda fundada: ¿Por qué existe mayor potestad para la iniciativa de las leyes respecto a la consulta en referéndum, si este no siempre tiene carácter vinculante? ¿Por qué puede darse la iniciativa popular de ciertas leyes sin que en igual proporción pueda darse la posibilidad popular de aprobarlas o derogarlas?

A lo anterior debemos agregar otro elemento crítico: dejar abierta la puerta para que, por medio del referéndum, pueda disponerse de las relaciones internacionales del Estado, lo que en esencia constituye un típico acto político. Quizás con consagrado optimismo, podría lograrse algún referéndum vinculante con el $40 \%$ a cuestas para aprobar una reciente reforma Constitucional que a duras penas enaltece la participación popular.

En todo caso, retomándose aspectos positivos del ordenamiento jurídico costarricense, existen también derechos procesales, conjuntamente con el derecho de acción procesal, en las diversas instancias jurisdiccionales y administrativas. El ciudadano se hace copartícipe, aunque sea de forma refleja, del control de los poderes públicos y del orden social, sea para la protección de los intereses legítimos y los derechos subjetivos, o a través de la acción pública penal y en espera de la aceptación expresa jurisprudencial, por virtud de la Ley de la Jurisdicción Constitucional (artículo 75), de la acción popular (interés legítimo objetivo) para la defensa de los intereses colectivos y los intereses difusos, aun cuando esté aceptada la legitimación objetiva para la interposición de la acción de inconstitucionalidad directamente, sin que se requiera de un asunto previo judicial o administrativo, lo cual ha sido confirmado en materia de protección ambiental o para la defensa del patrimonio histórico o cultural, entre otros ejemplos.

Ahora bien, en refuerzo de la tesis a favor de la acción popular, ya hemos entregado al Poder Judicial un proyecto del nuevo Código del Proceso Contencioso Administrativo, donde, en materia de legitimación activa, se acepta procesalmente la acción popular para la defensa de los intereses colectivos y los difusos, cuando una ley así lo disponga. No menos presente está la legitimación activa de los grupos, gremios, sindicatos, asociaciones y organizaciones afines, sin perjuicio de ampliarse la legitimación pasiva -entre otros- para los órganos con personería instrumental, bajo el principio de la rendición de cuentas. También debe ser incorporada a nuestro sistema positivo, por reforma del Código Municipal, la acción vecinal a fin de que 
los vecinos de cada cantón ejerciten la defensa debida y pronta de los bienes y derechos de la colectividad ante la negligencia de la Municipalidad.

Todo el conjunto de derechos procesales y materiales han de regularse por el principio de igualdad consagrado en el numeral 33 de la Constitución de Costa Rica, como parámetro sustancial en el ejercicio de los deberes y derechos democráticos. El artículo 39 ibid. realza el debido proceso como derecho fundamental. El numeral 41 consagra el derecho de acción procesal para las acciones de inconstitucionalidad (artículo 10), hábeas corpus y amparo (artículo 48), contencioso administrativa (artículo 49), laboral (artículo 70), penal (artículos 37 y concordantes), y por derivación del mismo artículo 41, se hace extensible a cualesquiera de las acciones procedimentales y procesales requeridas para la satisfacción reparadora de los daños y perjuicios ocasionados, sean de incidencia material o inmaterial.

Asimismo, en el encuentro de los valores de libertad, se garantiza la libertad de asociación (artículo 25), también la libertad de reunión para la discusión de intereses públicos y el control de la conducta de los funcionarios públicos (artículo 26). Existe garantía para el ejercicio de la libertad de petición (artículo 27), la cual he subdividido en derecho de resolución y derecho de información $;{ }^{29}$ la libertad de acceso a las oficinas públicas para información sobre asuntos de interés público, salvo secretos de Estado (artículo 30).

En lo que se refiere al pueblo como sujeto ideal subjetivo de la ordenación jurídico-política fundamental, y como fuente causal de la ubicación doctrinaria de las democracias, está la subordinación a tal voluntad para la potestad de legislar (artículo 105), para la conformación del Gobierno (Poder Ejecutivo) (artículo 9) y para los procesos de elección popular a niveles nacional, provincial y regional.

En cuando al plebiscito como consulta popular de grado provincial, la Constitución lo exige para su reforma parcial conforme al artículo 195, ante el eventual cambio de la actual división territorial del Estado, en cuyo caso debe ser votado y aprobado el proyecto de creación de nuevas provincias, con desmembración de las afectadas (artículo 168). Así, el plebiscito, por mandado supremo, es vinculante y obligatorio para los congresistas antes de la eventual reforma constitucional, lo cual impone también la voluntad popular organizada.

29 Vid. mi trabajo: "La libertad constitucional de petición y su efectiva protección jurisdiccional en la vía de Amparo". Revista Lustitia. No. 53, mayo 1991, pp. 8-14. 


\section{B. EL DERECHO DE PARTICIPACIÓN PARA LA ELABORACIÓN DE LAS DISPOSICIONES REGLAMENTARIAS DE CONFORMIDAD CON EL LIBRO SEGUNDO DE LA LEY GENERAL DE LA ADMINISTRACIÓN PÚBLICA (LGAP)}

\section{B.1 Previa ubicación doctrinal y positiva de los reglamentos}

La doctrina no es pacífica en la interpretación que hace de la naturaleza jurídica de las disposiciones reglamentarias. En términos simples y coincidentes, bien podría caracterizarse al reglamento como una actuación administrativa de alcance general, de rango inferior a la Ley pero con inserción en el ordenamiento jurídico escrito. Es el reglamento, entonces, una disposición normativa dictada por la Administración Pública.

La Ley y el reglamento tendrían así algo en común, pero solamente eso: el rango de la normativa escrita. En lo restante son totalmente distintos, como que la ley es la manifestación de la voluntad popular siempre superior a la manifestación administrativa, en cuanto soporte sustancial de la estructura política del Estado democrático. Por ello, la administración queda subordinada a la voluntad legal, a su letra y a su contenido, sin que pueda contradecir, violentar, disminuir, sustituir o eliminar la voluntad legal que impone respeto y seguimiento, con límites y atribuciones para la ulterior regulación reglamentaria. En todo caso, los reglamentos quedan sujetos a la voluntad popular expresada en la actividad legislativa (la ley), lo que finalmente convierte la voluntad administrativa en un efecto necesario de la otra voluntad superior, impulsora y guía de la subordinada.

Sin embargo, también podría suponerse la competencia reglamentaria desde la normativa constitucional, lo que no invalida, en modo alguno, la presencia de la voluntad comunitaria, porque la vigencia de la norma constitucional en plena confirmación -implícita o expresa- de su contenido regulador forma parte no solo de la legalidad sino también de la legitimidad (en principio). Asimismo, porque la Constitución es la fuente primaria y el techo del Derechos del Estado cuya configuración, generalmente, y en lenguaje democrático, es el resultado de la acción concertada entre todos y cada uno de los sectores políticos, económicos y sociales en el proceso constituyente originario o en la adaptación de la Constitución desde el poder constituyente constituido o por virtud de la mutación o adaptación constitucional en su contenido y no así en su forma normativa.

A su vez, encontramos en la actualidad dos sistemas jurídicos diferentes del común denominador, distanciados por sus posturas extremas: el sistema francés y el sistema anglosajón. El primero se deslizó, con la Constitución de 1958, por la potestad reglamentaria del Ejecutivo, sin necesidad de la previa existencia legal ordinaria para favorecer la derivación automática de la Constitución Política. Por esto, lo que es residual de la ley rige a favor del 
Ejecutivo y su potestad reglamentaria, razón por la cual el marco de referencia legal está categóricamente tasado. En lo conducente, el artículo 37 de la Constitución francesa dice: "Todas las materias distintas de las pertenecientes al dominio de la ley tendrán carácter reglamentario...”. El sistema inglés, en cambio, ha suplido el vacío constitucional de la potestad reglamentaria por delegaciones legislativas hacia el expreso reconocimiento de la potestad normativa del Ejecutivo. Entre ambos sistemas, es este el mecanismo puritano que sigue el principio de la separación de poderes, hoy división orgánica de funciones, en razón de que el Poder del Estado es uno, y los órganos múltiples, fundamentales o no, sin que la separación sea extrema, por la interacción entre estos que permite concluir prácticamente en un sistema de colaboración activa y en ocasiones de compenetración material fiscalizada y jurídicamente aceptada y regulada.

En todo caso, los reglamentos siempre deben garantizar la continuidad de los sistemas políticos en libertad y para la libertad, pues ellos nacen para garantizar una mayor agilidad administrativa en el cumplimiento de sus cometidos ad intra y ad extra para la satisfacción de intereses públicos, con plena sujeción al control judicial que garantice, aun con aplicación de la discrecionalidad, la subordinación al principio de legalidad entendido como principio de sujeción objetivo al ordenamiento jurídico.

En esa misma postura de judicialización del sistema, debemos resaltar el artículo 106 de la Constitución española, que en lo conducente expresa: "Los tribunales controlan la potestad reglamentaria y la legalidad de la actuación administrativa, así como el sometimiento de esta a los fines que la justifican."

Desde la perspectiva positiva, en relación íntima con la doctrinaria, nuestro ordenamiento jurídico-administrativo (artículos 120 y siguientes de la Ley General de la Administración Pública - LGAP) sostiene la equiparación del acto administrativo con el reglamento. Este, a su vez, es un decreto de alcance normativo, siendo los decretos actos administrativos de alcance general, a diferencia de los acuerdos, que, aun siendo actos administrativos, son de alcance concreto.

Hay en nuestro ordenamiento jurídico-administrativo distintas caracterizaciones de los actos, sean o no de alcance normativo, sean de efectos generales o concretos (acuerdos) y sean internos o externos según su relación o no con los administrados (ciudadanos), clientes o usuarios de los servicios públicos. En esta tesitura, todo reglamento es un decreto pero no todo decreto llega a ser siempre un reglamento. ${ }^{30}$

30 En ese mismo lineamiento vid, entre otros, en la doctrina italiana: Giannini, M. S. "Provvedimenti amministrativi generali e rogolamenti ministeriali. Sugli atti amministrativi generali a contenuto non normativo", en: Foro italiano. 1954, IV, p. 220. 
Un acuerdo administrativo nunca podría ser decreto ni reglamento. Por lo anterior, los actos administrativos podrían ser internos y externos, generales o individuales, reglamentarios o no reglamentarios. Encontramos así dos grandes contextos de la actuación administrativa: los hechos administrativos y los actos administrativos, y dentro de estos, los actos reglamentarios que aun siendo normativos son también actos administrativos. ${ }^{31}$

Y al ostentar la misma naturaleza de los actos administrativos, amén de lo indicado, se daba la posibilidad, antes de las reformas puntuales de la LGAP por parte del Código Procesal Contencioso Administrativo, de que un reglamento que no fuera impugnado en tiempo y forma, tanto en el procedimiento con vicios de plena nulidad ( 4 años) como en el proceso ( 4 años), se trasformaba así, desde su eficacia y ejecución, en el equivalente al acto válido, aun adoleciendo de vicios de nulidad absoluta. El tiempo así mal aprovechado por la omisión de accionar de algún interesado, sumada a la inescrupulosa e ilegítima pasividad administrativa, permitía al final que lo inválido fuera ejecutado, girando a su favor el escudo de la no impugnación por parte interesada o para la anulación de oficio.

De esa forma, a nivel administrativo (LGAP), existía una gran -y grave- paradoja, a saber: los actos viciados de plena nulidad no tienen a su favor el principio de presunción de legitimidad de los actos ni puede ordenarse su ejecución; sin embargo, transcurridos los plazos fatales de impugnación y revisión oficiosa, se imposibilitaba la reversión in radice, sin que por esto talas actuaciones se convirtieran en válidas, pero con alcance suficiente para ser ejecutadas. Quedaban así abiertas dos vías para el control de rescate: una de naturaleza procedimental a través de la denuncia que no obliga a la Administración, y otra procesal por la acción de amparo ante la Sala Constitucional, sin que aquí se pueda prescindir del acto de aplicación individual, por repetido criterio jurisprudencial, a no ser para una potencial acción de inconstitucionalidad por acción directa -reitero-, de conformidad con el artículo 75 de la Ley de Jurisdicción Constitucional para la defensa de los intereses colectivos y difusos.

31 Esta tesis es mantenida por Garrido Falla: "Los reglamentos son fuente para la Administración pero proceden de ella misma. Esto determina que ofrezcan una doble vertiente: por su procedencia son actos administrativos sometidos al principio de legalidad y susceptibles, en su caso, de ser fiscalizados por la jurisdicción contencioso-administrativa; por su contenido son normas de Derecho objetivo (norma agendi), por lo que, según la conocida expresión de Hauriou, vienen a integrarse en el llamado "bloque de la legalidad", que se impone a la propia Administración en su actuación concreta”. Del autor: Tratado de Derecho Administrativo, Madrid, Centro de Estudios Constitucionales, 1985, novena edición, T. I, p. 363. En semejante postura, con un análisis crítico de la posición contraria mantenida por García de Enterría y Fernández Rodríguez, y otros autores que seguidamente destacaremos, está Entrena Cuesta. Curso de Derecho Administrativo. Madrid: Editorial Tecnos, quinta edición, 1976, pp. 90-108. En análoga posición vid. Benvenuti F. "La impugnación de los reglamentos", en: Revista del Seminario Internacional de Derecho Administrativo. Colegio de Abogados de Costa Rica, 1981, pp. 550-551. Por su parte, sostiene Vedel G. en la perspectiva francesa: "El acto reglamentario no es más que una variedad de la decisión ejecutoria; es uno más entre los actos administrativos; no participa para nada de la soberanía ni de la infalibilidad de la ley”. Vid. Derecho Administrativo. Madrid: Aguilar, 1980, pp. 149-150. Los reglamentos son, en síntesis, decisiones ejecutivas generales e impersonales. 
En razón de lo anterior y con seguimiento de la lógica intrínseca para los actos viciados de plena nulidad, en el Código Procesal Contencioso Administrativo se plasmó en su regulación procesal, y por reformas a la LGAP, una vía intermedia que hace posible la impugnación con apertura de plazo, una vez vencido el tiempo anual para que las partes o la Administración de oficio ataquen el acto viciado con efectos hacia el futuro o ex tunc. ${ }^{32}$ De esa forma, con la nueva regulación se estaría ante conductas o actuaciones con grado de patología extrema y con permanencia de sus efectos en el tiempo y espacio más allá de la señalada anualidad, por lo cual podrían ser objeto de impugnación o anulación oficiosa con dimensionamiento ex post $\mathrm{o}$ ex nunc. Así, entonces, se atendió, con nueva dinámica procedimental y procesal en el citado Código, una inquietud sobradamente fundada ante las actuaciones viciadas de nulidad absoluta, a saber: la imposibilidad que existía para la impugnación o la revisión oficiosa, pasados los referidos 4 años, aun cuando la ejecución de la nulidad absoluta permaneciera vigente. La consecuencia ilógica y desproporcionada habría de ser una: la existencia de conductas viciadas de plena nulidad con grado de eficacia jurídica, por razón del imposible ataque procesal por el tiempo transcurrido, aunque la naturaleza del vicio reclamara su extirpación radical, en aras de la seguridad colectiva e individual.

Otro de los elementos dignos de meditación crítica es que si se identifica el acto administrativo con el reglamento, tendríamos que aceptar la posibilidad de que este pueda ostentar vicios de mera anulabilidad o nulidad relativa, lo que podría dar paso al saneamiento, convalidación y conversión (aspecto este extensible a los actos de nulidad absoluta según criterio de la LGAP -art. 189-, lo cual en sentido estricto no debiera ser, porque una nulidad radical no se convierte, simplemente debe desaparecer para dar nacimiento a un nuevo acto jurídico), lo que permite la corrección del acto viciado a pesar de tener rango normativo y estar incorporado al ordenamiento jurídico escrito. Insisto: en esto, el control debiera ser extremo: al igual que la violación del procedimiento legislativo acarrea la plena nulidad de su resultado final que es la ley, el reglamento debería también tener el mismo grado de control efectivo y radical ante las violaciones del procedimiento de elaboración de estas disposiciones generales, lo que en todo caso está expresamente regulado en la LGAP.

Existen otras disposiciones que debemos resaltar en esta materia reglamentaria. En la LGAP se dan distintas disposiciones para la amplia gama de actos administrativos. Una de ellas se relaciona con la teoría proclive a "las reglas y principios que regulan los actos administrativos" (artículo 6.3): para todo aquello que no esté regulado para los reglamentos,

32 Dice el artículo 175 de la LGAP: "Caducará en cuatro años la potestad del administrado para impugnar el acto absolutamente nulo en vía administrativa y jurisdiccional, sin que se apliquen al respecto los plazos normales de caducidad". Sostiene el artículo 173.4: "La potestad de revisión oficiosa consagrada en este artículo caducará en cuatro años". 
aplicándose el régimen común de los actos administrativos en general. También existen claras puntualizaciones para los reglamentos, como la prohibición de dictarse reglamentos autónomos relacionados con los derechos constitucionales, a no ser mediante reglamentos ejecutivos con previa ley habilitante (artículo 19), o la imposibilidad de dictarse penas e imponer exacciones, tasas, multas o cargas similares (artículo 124), lo cual es extensible a todo acto administrativo de alcance general.

Tampoco puede otorgarse a las administraciones públicas potestades reglamentarias de imperio que afecten los derechos de los particulares "extraños a la relación de servicio" (artículo 12,2). Sin embargo, pudiera suponerse, contrario sensu, el advenimiento de esa potestad cuando afecten los derechos de los particulares en sus relaciones de servicio con la Administración. Empero, tal dinámica, sacada a relucir por exclusión interpretativa, tiene una exigida -y obligada- agudización legal. En primer término, debe distinguirse en perspectiva práctica los derechos del ciudadano y, en segundo orden, los derechos de los ciudadanos en la relación funcionarial de servicio.

La Administración no puede dictar ni ejecutar actos reglamentarios internos ni externos que afecten los derechos de los administrados (ciudadanos) (artículos 103.1 y 122 ibíd.). En caso de ejecución de tales actos, cabría la responsabilidad del Estado o la corresponsabilidad de este con el o los funcionarios singularizados. Ahora bien, resulta posible la existencia de actos internos de relevancia externa, regulados por ley, por reglamento "u otra norma cualquiera del Estado" que no afecten los derechos del ciudadano. Como también sería viable la vía reglamentaria con afectación de los derechos de los funcionarios públicos en su relación de servicio con la Administración, por actos internos que adquieren rango de actos externos, sea frente a los ciudadanos o ante los tribunales comunes (artículo 123 ibid.). Puede así haber potestad de imperio a nivel reglamentario, de cuyo cumplimiento se afectan los derechos de los servidores en su relación de servicio con la Administración, sin que esto sea válido ni eficaz para aquellos actos internos o externos contra los derechos de los ciudadanos.

Hay otro sector de la doctrina que sigue una traza distinta a la mantenida en la LGAP, hoy prevaleciente, que distingue el acto administrativo del reglamento, aun siendo este un acto de la administración. ${ }^{33}$

33 En tal sentido, se expresa García de Enterría en: "Recurso contencioso directo contra disposiciones reglamentarias y recurso previo de reposición”, en RAP. No. 29, p.161, cuyas ideas son retomadas y ampliadas en: Legislación Delegada, Potestad Reglamentaria y Control Judicial. Madrid: Editorial Tecnos, 2da. ed., 1981, in totum. Asimismo, en unidad con el profesor Fernández Rodríguez, vid. Curso... op. cit., pp. 104-107. También de este último autor: Derecho Administrativo Económico. Madrid: UNED, 1980, pp. 63-64. En este mismo encuadre doctrinal, entre otros, Boquera Oliver. "La publicación de disposiciones generales", en RAP. No. 31; Martín Mateo. Manual de Derecho Administrativo. Madrid, 1979 , pp. 129-131. 
Seguidamente, bien haríamos en englobar los argumentos fundamentales de esta postura distanciada de la otra: a) El reglamento se incorpora al ordenamiento jurídico, pues su carácter es normativo u ordinamental. b) Los reglamentos que tengan vicios son siempre vicios de nulidad absoluta, con lo que se trasciende el vicio formal de sustancia, sea por violación del debido procedimiento tasado por ley, o por violación de un reglamento de rango superior. Así, pues, el régimen exclusivo de nulidad para el reglamento es el de la plena nulidad, mientras que para el acto administrativo el régimen normal es el de la mera anulabilidad, siendo excepcional el de la nulidad absoluta. c) El reglamento no puede derogarse de manera singular por su trascendencia jurídica, sin que pueda un acto administrativo contradecirlo o desaplicarlo, aun cuando tal acto provenga de la misma autoridad o de una autoridad superior que dictó el mismo reglamento. El reglamento, por su contexto normativo, adquiere naturaleza de aplicación abstracta y permanente. No se agota con su cumplimiento, a diferencia del acto administrativo que así lo hace. d) La potestad reglamentaria recae en los órganos a los que las normas de producción atribuye específicamente. En cambio, para el dictado de actos administrativos generales no se exige el pronunciamiento de las normas de producción. Sin embargo, esta postura también ha sido criticada parcialmente por un distinguido autor. ${ }^{34} \mathrm{En}$ efecto, entre sus fundadas críticas podrían destacarse las siguientes: a) La tajante distinción entre acto y reglamento no adquiere la transparencia acusada. b) Se debe admitir que los principios de la generalidad y la abstracción reglamentaria están en crisis. Sin embargo, en su criterio, en lo que coincide con la doctrina en general, no puede admitirse la singularidad normativa y de aplicación reglamentaria. Ahora bien, a pesar de lo anterior, existen reglamentos singulares en el único ámbito interno de la organización administrativa como unidad organizacional. También existen reglamentos "singularizables" cuyo número de destinatarios es determinado, pero no exclusivo, con grado de generalidad aplicativa para hipótesis semejantes hacia el futuro. Debe diferenciarse, pues, entre reglamento singular y reglamento singularizable. c) El criterio positivo aunado al principio de consunción o extinción del acto administrativo, cuando este se cumple y aplica, a diferencia de la trascendencia reglamentaria, no explica la trascendencia o permanencia habida en algunos actos administrativos singulares. A manera de ejemplo se tiene el nombramiento de un funcionario público, cuyo acto no se extingue o consume por el nombramiento ni por la toma de funciones, antes bien, por el contrario, el acto continúa siendo eficaz con el desempeño funcionarial o en otras hipótesis con la ejecución del régimen funcionarial. d) Entre el acto administrativo singular y el reglamento hay toda una escala progresiva de generalidad o acaso regresiva de singularidad, que no permite la nítida distinción fronteriza entre acto y reglamento, siendo imposible destacar los mojones separadores con criterio seguro e irrebatible. e) El problema de la distinción "es un

34 Me refiero a Santamaría Pastor. Apuntes de Derecho Administrativo. Quinta edición. Madrid. 1987, pp. 515-517. 
falso problema”, pues todo puede reducirse al tratamiento dado por el legislador -o por las leyes- en la aplicación de regímenes jurídicos diferentes para los reglamentos y para los actos administrativos.

Este último criterio se hace copartícipe, entonces, con sus propias matizaciones, de la universalidad de tratamiento entre acto administrativo y reglamento, favoreciéndose su unidad jurídica. Pero con ello, creemos, no queda satisfecho el problema práctico de su fusión sustancial, la cual ha sido sobradamente rebatida por otro sector ya comentado de la doctrina. $\mathrm{Y}$ todo radica, en esencia, en una verdad incuestionable, a saber: el alcance normativo del reglamento y los elementos caracterizadores de los típicos actos administrativos.

\section{B.2 Distintos tipos de reglamentos}

Suele hacer la doctrina elaboraciones abundantes de tipologías reglamentarias, con reducción al fin, bajo la perspectiva pragmática, a tres tipos de reglamentos: a) los mal denominados ejecutivos, que en el fondo son reglamentos de complementación legal, toda vez que un reglamento válido siempre debe tener fuerza ejecutiva; b) los reglamentos independientes, autónomos o de organización administrativa; c) por último, los reglamentos de necesidad, en la aplicación excepcional y temporal frente a situaciones sobrevenidas de emergencia.

Siguiéndose en parte con la trilogía expuesta a mediados del siglo XIX en la doctrina alemana por Lorenz von Stein, en relación con los distintos tipos de costumbre, se elaboró una visión que en cierto modo ha perdurado hasta la actualidad: extra o prater legem, secum legem y contra legem. Maticemos con la brevedad del caso esta tipología reglamentaria.

\section{a. Los denominados reglamentos ejecutivos}

Los reglamentos ejecutivos son aquellos que amparados al contenido de una ley anterior la complementan con el desarrollo de regulaciones materiales y formales para la mayor flexibilidad y adaptación aplicativa de las decisiones administrativas. Esto ha permitido que se haya acusado a estos tipos de reglamentos de ser fuente derivada de Derecho en relación con los de fuente originaria, identificados con la ley. Es lo que von Stein denominó, en referencia a la costumbre, como "secundum legem".

En el contexto positivo de nuestra Constitución, el artículo 140 inciso 3) otorga al Poder Ejecutivo en sentido estricto (Presidente y respectivo Ministro del ramo) la potestad de reglamentar las leyes.

En este tratamiento de la potestad reglamentaria, ha dicho la jurisprudencia constitucional, en relación con los principios rectores de una democracia activa: "La facultad reglamentaria está reducida a parámetros muy definidos que la condicionan y limitan, puesto que la misma 
en ningún caso puede violentar la dinámica propia e inmanente que deriva de la división de poderes y que constituye, por así decirlo, la esencia misma del sistema democrático. Uno de esos parámetros fundamentales de la facultad reglamentaria es el hecho de que, dentro del sistema democrático, los poderes públicos tienen claramente definidas sus funciones, sin que pueda ninguno de ellos asumir las propias de los otros, pues tal trasgresión viola flagrantemente el concepto mismo de la división de poderes que recogen de diversa manera los artículos 9, 11, 121 inciso 1) y 140 incisos 3) y 18) constitucionales". (SCV 0031- 95, también 1130 - 90; 1635- 90; 1876- 90 y 243-93)

En lo que respecta a la jurisprudencia indicada sobre la potestad reglamentaria ejecutiva, se ha dicho, entre mucho, lo siguiente: "Como tesis de principio, puede afirmarse que la potestad reglamentaria, esa competencia que se le asigna al Poder Ejecutivo de desarrollar la ley (reglamento ejecutivo) no es un poder-deber en sí mismo, puesto que dependerá del contenido de la propia ley el que aquel se vea obligado a desarrollar algunos de sus principios, pues correspondiendo al Ejecutivo aplicar o velar porque la ley se aplique, en tanto sea necesario para ellos decidirá su reglamentación. Es decir, la reglamentación se otorga al Ejecutivo como un instrumento que facilita el ejercicio de administrar". (SCV 2934- 93)

Asimismo, “(d)entro de los reglamentos que puede dictar la Administración, se encuentra el que se denomina 'Reglamento Ejecutivo', mediante el cual ese Poder en ejercicio de sus atribuciones constitucionales propias se utiliza para hacer posible la aplicación o ejecución de las leyes, llenando o previendo detalles indispensables para asegurar no solo su cumplimiento, sino también los fines que se propuso el legislador, fines que nunca pueden ser alterados por esa vía. Ejecutar una ley no es dictar otra ley, sino desarrollarla, sin alterar su espíritu por medio de excepciones, pues si así no fuere, el Ejecutivo se convierte en legislador" (SCV 2934-93). “... solo los reglamentos ejecutivos pueden desarrollar los preceptos de las leyes, entendiéndose que no pueden incrementar las restricciones establecidas ni crear las no establecidas por ellas, y que deben respetar rigurosamente su contenido esencial”. (SCV 2934- 93)

\section{b. Los reglamentos, independientes, autónomos o de organización}

Son reglamentos independientes aquellas disposiciones autónomas para la organización interna de los entes y órganos administrativos, así como también de los órganos fundamentales del Estado y de rango constitucional.

La potestad reglamentaria de organización puede devenir expresamente del texto constitucional o acaso implícitamente, o por derivación de la potestad discrecional administrativa para la satisfacción de los intereses públicos, siempre cambiantes en el tiempo y el espacio. Se ha insistido, en parte, que los reglamentos independientes, autónomos o de 
organización ostentan el rango de norma primaria, no así secundaria por la no complementación necesaria de la ley anterior que autoriza y exige su desarrollo ulterior. Sin embargo, es cierto también que aun sin ley anterior no puede el reglamento autónomo contradecir ni derogar cualquier ley por virtud de las fuentes materiales del ordenamiento. La potestad reglamentaria en todo caso se deriva de una u otra manera de la Constitución Política, sea escrita o no, lo que al final de cuentas se traduce en la normativa autorizante y causal de forma expresa o implícitamente, o directa o reflejamente. Los principios del servicio público de la igualdad, continuidad, eficiencia y adaptabilidad a los cambios sobrevenidos de hecho y de derecho en ocasiones están identificados en el texto constitucional, aunque solo sea parcialmente. Efectivamente, como ya lo resaltó el voto constitucional número 04-006216-0007-CO, la Constitución regula, algunas veces de forma clara y otras derivadamente, los principios del servicio público dispuestos en la LGAP, a saber: continuidad, eficiencia, adaptación a los cambios sobrevenidos de hecho y de derecho e igualdad. A esos debemos agregar, entonces, los principios de razonabilidad, proporcionalidad, eficacia, simplicidad y celeridad, siendo así que los artículos 139 inciso 4 ("buena marcha del gobierno"), 140 inciso 8 (deber del Ejecutivo en "vigilar el buen funcionamiento de los servicios y dependencia administrativas") y 191("eficiencia de la Administración") confirman, todos, la magistral presencia normativa a nivel constitucional.

En nuestro sistema positivo, por virtud de la LGAP, tales principios quedan insertos en el conjunto de la actividad y organización administrativas, sobre los cuales descansa el ejercicio discrecional para satisfacer los intereses públicos nunca confundidos con los intereses de la Administración ni con los intereses egoístas del particular. Por consiguiente, los reglamentos autónomos o independientes son originarios en su materia reguladora a falta de ley anterior y de contenido apenas tímido y parcial. Pero nunca podrían ser originarios o primarios, como si nacieran con absoluta independencia del ordenamiento jurídico, cuya discrecionalidad aplicativa siempre debe estar regulada por los parámetros prefijados de la legalidad en su dimensión escrita y no escrita, o, si se quiere, de la Ley y el Derecho (artículo 103 de la Constitución española). Aunque tales reglamentos sean independientes, quedan siempre subordinados a los límites de la potestad reglamentaria, sin que puedan ubicarse por encima de la voluntad popular expresada en la ley -principio democrático- o de la comunidad políticamente organizada que la posibilita y protege, tanto en función de la legalidad como de la legitimidad.

Estos reglamentos autónomos o de servicio quedan adentrados en el ejercicio de la potestad organizacional de las administraciones públicas y de otros órganos que, en la creación y manifestación de tal potestad, expresan una función estrictamente administrativa, aun cuando su regulación no quede incluida en la esfera típica de la organización administrativa del Es- 
tado. Y es precisamente a través de la manifestación de esta potestad autorreguladora de los otros órganos fundamentales del Estado como el Legislativo, el Judicial y el Tribunal Supremo de Elecciones, que se logra confirmar, entre otras realidades jurídicas, la división orgánica de funciones, cuando tales órganos ejercitan potestades materiales que son del típico resorte del Ejecutivo o de la Administración Pública institucional o territorialmente definidas.

\section{c. Los reglamentos de urgencia o necesidad}

En situaciones excepcionales de emergencia no cabe la aplicación normal y ordinaria administrativas, pues ello iría en contra del interés público que impone la pronta solución, incluyéndose la aplicación de medidas cautelares prima facie o anticipativas, para hacer frente a una situación imprevisible e inevitable, o acaso previsible pero inevitable. Aplicar la normalidad procedimental y sustancial en situaciones anormales es tan grave como hacer lo anormal en situaciones normales, contra el clásico principio democrático de la salus populi suprema lex est.

En sentido estricto, pues, y siguiéndose lo ya apuntado entre ley y Derecho, los reglamentos de necesidad no siempre son ni debieran ser contra legem. Simplemente son excepcionales conforme al texto y contexto valorativo del ordenamiento jurídico.

Ahora bien, tales reglamentos podrían contradecir de manera eventual el texto riguroso de la ley, pero no así el espíritu equilibrado de la proporcionalidad, razonabilidad, seguridad, lógica, los criterios unívocos de la ciencia, la técnica, buena fe, justicia y los restantes principios generales del Derecho. Decir que son contra legem no es una verdad necesaria, y por lo tanto medianamente cierta: pueden existir reglamentos de necesidad no opuestos a la letra de la ley, y en todo caso nunca deben estar disconformes con el ordenamiento jurídico y sus principios reguladores. Asumir lo contrario sería tan absurdo como convertir la emergencia en la justificación administrativa para aumentarla o acaso ignorarla, sin evitación de la crisis o de su necesaria corrección. La excepcionalidad jurídica debe ser única y exclusivamente frente a la situación anormal, la cual, una vez consumada, no deja mérito ni espacio alguno para que las administraciones puedan continuar con el ejercicio de esa potestad privilegiada, sin el elemento fáctico justificante y excepcional.

En todo caso, y aun en emergencia, los funcionarios públicos son potencialmente responsables en lo administrativo, en lo civil y en lo eventualmente penal por sus conductas omisas o activas. La Administración pública, por definición, debe ser agente de satisfacción de intereses públicos, nunca el instrumento multiplicador o realizador de inseguridades colectivas e impulsoras de angustias por temores compartidos sin soluciones puntuales ni efectivas. 
Así, de esa forma, si bien es cierto que la discrecionalidad administrativa se hace evidente en el uso de la potestad reglamentaria para la organización interna, aún es mayor el grado de aplicación discrecional en situaciones de emergencia donde en ocasiones incluso no existe normativa reguladora sino simples principios rectores de comportamiento claramente identificados para el ejercicio de la potestad administrativa. No podríamos asumir que en tales situaciones de anormalidad fáctica y jurídica la Administración pueda dictar actos con rango de ley -al menos en nuestro sistema jurídico- ni actos que la contradigan o violen, e incluso, en caso de estarse ante una situación de vacío o laguna jurídica, la jurisprudencia, la costumbre y los principios generales del derecho quedarían elevados a rango de norma escrita -se insiste- en función supletoria del ordenamiento escrito, para la satisfacción de los intereses públicos. El círculo de la debida, continua, eficiente y eficaz actuación administrativa se cierra a favor de los derechos y necesidades ciudadanas.

Dos son las dudas ante los reglamentos de urgencia: a) De una parte, su posible extensión excepcional en el tiempo, haciéndose que su aplicación se transforme en situación regular o de larga data, siendo así que se llegaría a confundir gravemente la disposición general derivada de la urgencia con el reglamento ejecutivo, sin que existan, por lo general, leyes preestablecidas al efecto. b) De otra parte, podrían surgir reglamentos de emergencia en situaciones normales con el fin de regular potenciales realidades excepcionales con fundamento en la previsión técnica o política, o acaso en realidades anteriores dentro o fuera de las fronteras nacionales. Este fatal implante de la excepcionalidad en la normalidad, so pretexto de múltiples excusas y acomodos institucionales para la concentración de poder público, confirmaría una grave e ilegítima realidad: el incumplimiento con la audiencia previa a los sectores y organizaciones virtualmente afectados con el reglamento, conforme a la exigencia para la elaboración de las disposiciones generales sin distingo, según el Libro Segundo de la LGAP. Esta segunda hipótesis encuentra confirmación en situaciones fácticas que imponen medidas de emergencia para solucionar afectaciones a los intereses públicos, sin la existencia de alguna disposición reglamentaria que pudiera solucionar el conflicto sobrevenido. Un ejemplo en nuestro medio aclara lo indicado, a saber: la huelga de los expendedores de combustible, que, en calidad de adjudicatarios o permisionarios del Estado, no lleguen a prestar-como no lo hicieron en algún momento en el pasado- el servicio al gran público, con efectos negativos para la economía nacional. Por ello, a fin de evitar situaciones análogas a futuro, se dictó una reglamentación de urgencia en situación normal, lo que evidentemente violentó la Constitución y la Ley ordinaria.

Así pues, suele encontrarse en la legislación comparada límites claros y precisos para impedir que una regulación de urgencia se mantenga en el tiempo más allá de lo dispuesto en la ley, que evita -o debe hacerlo- que lo excepcional se haga normal, sin darse posibilidad para 
la ratificación del abuso de autoridad y de actuaciones materiales bajo excusas, muy propias del devenir latinoamericano, de situaciones de urgencia y necesidad, no infrecuentemente generadas desde el Estado, para satisfacer los intereses de la cúpula gobernante, de sus clientes y allegados.

En razón de lo anterior, debemos indicar que un reglamento de "urgencia" dictado en situación normal para potenciales realidades excepcionales en modo alguno podría ignorar el debido procedimiento para la elaboración de las disposiciones reglamentarias, como si fuese un reglamento ejecutivo antes que uno de urgencia, por su nacimiento en la normalidad que impone también la normal satisfacción del ordenamiento jurídico, esta vez por actos reglados a favor de la transparencia y pluralidad participativas en su proceso de elaboración.

\section{B.3. Análisis del mecanismo regulador para la elaboración de las disposiciones reglamentarias}

España y Costa Rica, además del idioma y cierta idiosincrasia costumbrista e institucional, tienen algo más en común: dos fechas coincidentes en un mismo año en el que se forjó un importante surco de justicia, seguridad y libertad. España con la Constitución concertada que marcó el derrumbe del ancien régime y la nueva construcción de la edificación social y política, económica y jurídica. Costa Rica con su LGAP que estructura y ordena el ejercicio del poder administrativo, para que el público satisfaga su interés y el ciudadano proteja su esfera existencial de libertades y derechos, y para que la Administración sea agente de la democracia, aliada y no enemiga de sus valores y fines. Queda, sin embargo, mucho por recorrer, por cumplir y mejorar en la marcha de la práctica que impone observación cuidadosa de los errores para rectificarlos y superarlos. Ello es parte de la democracia en la vivencia dialéctica.

La LGAP ha creado sin duda paradigmas jurídicos en el devenir histórico nacional, hasta el grado de convertirse en una "ley principista", por lo que debe ser analizada desde la doble razón práctica y teórica. Lo mismo, creo, se dirá en España de lo suyo cuando las construcciones normativas alcancen cierto grado de patrimonio defendible, sin que sea intocable, dogmático o incuestionable.

Por su parte, la LGAP incorporó, como lo hizo España, al igual que otros países de perfil occidental, procedimientos especiales para asegurar la participación ciudadana en el quehacer administrativo. Sin embargo, España no se quedó en la regulación ordinaria sino que elevó la premisa democrática a rango constitucional. En lo conducente -entre otros numerales dignos de encomio-, el artículo 105 dice: "La Ley regulará: a) La audiencia de los ciudadanos directamente o a través de las organizaciones y asociaciones reconocidas por la ley, en el procedimiento de elaboración de las disposiciones administrativas que la afecten...”. 
Tenemos causalmente lo siguiente, a partir de la indicada disposición constitucional: 1) Es obligación de las administraciones públicas dar la audiencia de rigor a las personas físicas o jurídicas, en el procedimiento de elaboración de los reglamentos que potencialmente las afecten. 2) Existe el derecho de participación ciudadana de forma directa y no así solo de manera indirecta ante la hipótesis de no estar incorporado a alguna organización o asociación reconocidas por ley. 3) En el evento de que se encuentre adscrito a alguna organización o asociación, su derecho participativo podría filtrarse a través de tales estructuras jurídico-sociales y, finalmente, por medio de los representantes de ellas. La participación sería así indirecta o refleja. 4) Solo las organizaciones y las asociaciones -que también lo son- tienen derecho participativo (al igual que el ciudadano), no así cualquier aglomeración subjetiva emergente en la sociedad sin unidad u organización, o que organizadas estén jurídicamente prohibidas. 5) No puede desconocerse el derecho de participación ciudadana en igualdad de condición para la participación en el procedimiento, bajo el mismo supuesto de potencial afectación por la regulación reglamentaria. 6) Podría suponerse que un ciudadano en su esfera vital de intereses y derechos sea potencialmente afectado de forma directa por la futura reglamentación y, asimismo, en su calidad de agremiado o asociado lo sea también de forma indirecta. Cabría pues suponer la correlación participativa si fuera materialmente posible. 7) Como el derecho de asociación es un derecho fundamental incorporado en el artículo 22 de la CE, no podría entonces exigírsele al ciudadano su previa incorporación asociativa para el posterior ejercicio del derecho participativo. 8) Sin embargo, existen incorporaciones obligadas para el ejercicio de los derechos-deberes, tal y como sucede con algunos Colegios profesionales. El ciudadano puede hacer valer su derecho participativo a través de la corporación, sin que por ello se excluya el derecho de participación directa en calidad de ciudadano. 9) Correspondería a la ley regular la audiencia bajo los parámetros constitucionales de participación. En razón de lo anterior, el artículo 130 inciso 4) de la Ley de Procedimiento Administrativo español, el cual quedó vigente por expresa disposición no derogada de la Ley de Régimen Jurídico de las Administraciones Públicas y del Procedimiento Administrativo Común (RJAP-PCA), no tiene el mismo espíritu extensivo constitucional que satisface en esencia los parámetros de la igualdad, constitucionalmente garantizada (artículos 14 y 149 inciso 11). Este sentido se expresa claramente en la doctrina constitucional española. ${ }^{35}$

La disposición de la LPA tendría entonces en principios tres graves inconvenientes (o acaso inconstitucionalidades): a) Se deja a la discrecionalidad administrativa (lo que ya despierta

35 Vid. al respecto: Comentarios a la Constitución. op. cit. p. 1452. Dice, en lo que interesa, el artículo 130, incisos 4 y 5 de la LPA, hoy incorporado a la nueva legislación procedimental administrativa de España: "4. Siempre que sea posible y la índole de la disposición lo aconseje, se concederá a la Organización Sindical y demás entidades que por ley ostenten la representación o defensa de intereses de carácter general o corporativo afectados por dicha disposición, la oportunidad de exponer su parecer en razonado informe en el término de diez días, a contar desde la remisión del proyecto, salvo cuando se opongan a ello razones de interés público debidamente consignadas en el anteproyecto. 5 . Cuando, a juicio del Ministro, la naturaleza de la disposición lo aconseje, será sometida a información pública durante el plazo que en cada caso se señale...”. 
desconfianza) el dar o no la audiencia procedimental. Así, en primer lugar, dice la referida Ley: "Siempre que sea posible", lo que permite que sea también imposible y, por ello, nunca necesario; en segundo lugar, cuando "la índole de la disposición lo aconseje", lo que da paso, por lógica oponible, a que no lo aconseje, como si la potencial normativa por sí lo aconsejare o no. Simplemente, la mecánica es preceptiva y deberá proceder la audiencia cuando la disposición vaya a producir afectación ciudadana en menor o mayor grado. Ha de darse audiencia cuando pueda existir afectación o, en términos de la ley, existe el "consejo" cuando la Constitución lo pide. Lo que implicaría, también, que la audiencia podría darse para cualquier ciudadano u organización según la disposición normativa. De esa forma, entonces, se viola el principio de igualdad y se produce un trato discriminatorio entre las personas físicas y las personas jurídicas, lo que también contradice valores de jerarquía normativa y de seguridad jurídica, constitucionalmente garantizados (artículo 9.3 CE).

La LGAP de Costa Rica adolece de semejantes defectos, aunque no exista en nuestro país lo que es penoso- un precepto constitucional análogo, sin que por ello dejen de darse algunos lineamientos normativos, siempre escasos y tímidos cuando existan.

\section{B.3.i Subsiguiente análisis del artículo 361 de la LGAP}

Dice al texto el artículo 361 de la LGAP: "1. Se concederá audiencia a las entidades descentralizadas sobre los proyectos de disposiciones generales que puedan afectarlas. 2 . Se concederá a las entidades representativas de intereses de carácter general o corporativo afectados por la disposición la oportunidad de exponer su parecer, dentro del plazo de diez días, salvo cuando se opongan a ello razones de interés público o de urgencia debidamente consignadas en el anteproyecto...".

De lo anterior destaquemos lo siguiente:

1) En Costa Rica, el derecho de audiencia se hace extensible a los entes descentralizados, lo que supone la posible participación interadministrativa.

2) Solo las entidades representativas de intereses generales o corporativas, además de los entes descentralizados, tienen derecho de audiencia en el plazo de Ley. Podría suponerse la actividad multiparticipativa y mixta tanto en la vertiente pública administrativa como en la pública no estatal, al igual que la propiamente privada. E incluso también podría darse el desdoblamiento administrativo para la confirmación participativa, sea en el ejercicio de su capacidad pública o en el de su capacidad privada, según sea el ámbito de amenaza o afectación. $\mathrm{Y}$ en régimen confirmatorio de la igualdad, la audiencia a las administraciones deberá darse en el mismo plazo, esto es, "dentro de los diez días", los cuales deben entenderse siempre hábiles, por expresa disposición de la LGAP. 
3) Se excluye por ende la participación ciudadana en su dimensión física y directa, lo que contraría el principio de igualdad frente a las entidades, asociaciones y corporaciones, además de suponer la violación del artículo 33 de la Constitución Política, con incidencia refleja y contraria a la letra y espíritu de su numeral 25, que regula y garantiza la libertad de asociación para fines lícitos. En otros términos: a nadie se le puede obligar a formar parte de asociación alguna, lo que la LGAP afecta de manera indirecta cuando imposibilita el derecho de audiencia para la elaboración de los reglamentos a las personas físicas, toda vez que deben estar asociadas para el ejercicio de su derecho participativo. En modo alguno podríamos relacionar únicamente a las aplicaciones reglamentarias con las personas jurídicas, toda vez que es fácil comprobar su incidencia directa o bien indirecta en las esferas de derechos y libertades de los sujetos físicos, aun sin que medie un acto administrativo de aplicación individual. Ello también contraviene el artículo 49 de la Constitución costarricense, que manda del legislador proteger al menos los intereses legítimos y los derechos subjetivos, lo cual debe tener resonancia necesaria para las disposiciones reglamentarias, sin que tal defensa quede supeditada o condicionada a la existencia del acto singular en tanto haya amenaza de violación o violación efectiva.

4) Podría prescindirse del trámite de audiencia si el interés público o la urgencia así lo imponen, previa justificación incorporada al anteproyecto reglamentario. Sin embargo, es también de interés público el cumplimiento del procedimiento especial de elaboración, sobre todo cuando la misma LGAP categoriza ese interés "como la expresión de los intereses individuales coincidentes de los administrados" (artículo 113). Y ante la eventual afectación de intereses o derechos en el espacio de una mayor generalidad, por la naturaleza misma del reglamento, la posible suma de coincidencias individuales no constituye una labor de difícil o de imposible constatación adjetiva. Tampoco la Administración puede sobreponer su interés -se insiste- a la categoría cualificada que del ciudadano hace la LGAP, en tanto debe tenerse a este como representante de la colectividad (artículo 114, 1), en la tesitura de la valoración del interés público bajo el alero de la seguridad y la justicia, en los planos individual y comunitario, sin que pueda la simple conveniencia ocupar un lugar primigenio ( ibid., inciso 3). Este sería el mismo sentido que un autor con propiedad reclama: "El interés general abstracto y puro, que la Administración realiza como una organización compacta, es una ficción jurídica. El contenido de la actividad pública resulta de la combinación, distinta en cada caso, sujeta a las variaciones políticas, a los cambios en la relación de fuerzas, de los distintos intereses que emergen en un determinado momento y lugar. Las instituciones públicas realizan un papel de mediación de esos intereses. Pero, dada su trascendencia actual, tampoco son un simple árbitro que se limita a reflejar con exactitud las oscilaciones en la balanza de los intereses privados". ${ }^{36}$ De lo dicho, las administraciones públicas, a no ser por

36 Me refiero a Sánchez Morón. La participación del ciudadano en la Administración..., op. cit., pp. 31-32. 
casos de urgencia, encuentran un estrechísimo margen de justificación para satisfacer el interés público con trascendencia del derecho participativo que se entrecruza con otro conjunto de derechos en apertura permanente de reconocimiento universal.

5) Al estar el procedimiento de elaboración de las disposiciones generales tasado por ley, es obvio que su violación constituiría una alteración sustancial del ordenamiento, por lo que tal actuación estaría viciada de nulidad absoluta. No cabría oponer la tesis favorable para el simple vicio de forma, toda vez que es vicio sustancial y objetivo. El principio de legalidad (con inclusión del debido procedimiento) estaría quebrantado y su vicio deberá ser objeto de purga jurídica a gestión de parte o de oficio, siendo la nulidad, en todo caso, notoria o evidente a falta de audiencia obligada. Ejecutar un reglamento en tal hipótesis, dentro del encuadre general de los actos administrativos, podría acarrear responsabilidad funcionarial, por expresa prohibición de presumirse legítimos y eficaces actos viciados de nulidad absoluta.

6) En la hipótesis excepcional de que no exista audiencia por interés público o por urgencia -lo que suele interrelacionarse-, la Administración omisa deberá motivar las razones en el respectivo anteproyecto. En caso de no hacerlo sin que exista audiencia, hay vicio de plena nulidad, por la previa exigencia de su incorporación justificante.

7) Y en aplicación de la igualdad de trato, la falta de audiencia, en la hipótesis anterior, sería extensible a las administraciones públicas descentralizadas, lo que agudiza y reduce aún más la posible satisfacción del interés público sin la audiencia a tales administraciones, que en todo caso son agentes de ese mismo interés.

\section{B.3.ii Continuación del análisis del numeral 361 inciso 3) de la LGAP}

Dice este apartado 3 del artículo 361LGAP: "Cuando a juicio del Poder Ejecutivo o del Ministerio, la naturaleza de la disposición lo aconseje, el anteproyecto será sometido a la información pública durante el plazo que en cada caso se señale. "De forma análoga expresa el artículo 130 inciso 5) de la LPA de España: "Cuando a juicio del Ministerio, la naturaleza de la disposición lo aconseje, será sometida a información pública durante el plazo que en cada caso se señale".

De lo trascrito, hemos de decir lo siguiente:

1. Los contenidos normativos de ambas disposiciones son análogos, no así idénticos, conforme a la LGAP y la LPA. En Costa Rica no solo compete al respectivo Ministerio la aplicación discrecional y favorable para elevar un proyecto reglamentario a la información pública, sino además al Poder Ejecutivo en sentido estricto (Presidente de la República y respectivo Ministro del ramo o de los ramos). 
2. En todo caso, en ambas legislaciones existe una amplia potestad discrecional para determinar la procedencia o improcedencia del procedimiento público de información del proyecto reglamentario. En caso de confirmación positiva, la información requiere del uso del lenguaje claro e identificable para la amplia participación pública.

3. En ambas legislaciones se dice que tal procedimiento procederá si la naturaleza de la disposición lo aconseja, lo cual nos lleva a pensar en la simple aplicación unilateral administrativa en el ejercicio de la potestad discrecional. Por lo tanto, no sería el reglamento el que aconsejare, sino el Ministro o el Poder Ejecutivo quienes determinarían su aplicación o no, de conformidad con la interpretación y conveniencia, a veces más política que adentrada en la defensa de los intereses públicos.

4. Aunque se crea que la trascendencia del proyecto reglamentario requiera de la información pública, puede ser que tal mecanismo no se ponga en práctica por criterios administrativos, ante lo cual no se exige motivación alguna, a diferencia del régimen normal aplicativo, para la elaboración de las disposiciones reglamentarias, cuando por interés público o por urgencia no se da la audiencia de ley en el plazo de diez días.

5. Existen, entonces, destacadas diferencias formales y sustanciales entre el procedimiento de audiencia con sujetos virtualmente identificables y el procedimiento popular de información (pública): a) La discrecionalidad administrativa se aplica en ambas regulaciones, sea para obviar el procedimiento especial de audiencia en el plazo de diez días, por interés público o por urgencia, o para obviar el trámite de información pública del proyecto reglamentario. b) En la primera hipótesis de omisión, deberá darse la expresa motivación justificativa; en la segunda hipótesis, en cambio, la motivación no es exigida para la información pública. c) En la eventualidad de que proceda la audiencia de ley, deberá ser otorgada dentro del plazo de diez días hábiles. En cambio, en el caso de la información pública, existe discrecionalidad para la determinación temporal, sea o no mayor a los diez días hábiles. d) En una hipótesis, la audiencia se dará para los destinatarios cuyo potencial reglamento vaya a afectar sus esferas de derechos o intereses. En el otro caso, se daría la información pública con potencial participación popular más allá de la afectación directa o simplemente indirecta. E) Por lo anterior, sería fácil concluir que en el caso de la información pública sería tanto para las personas físicas como para personas jurídicas, por lo cual no sería procedente que fuera solo para las personas jurídicas. f) Hay, pues, dos regímenes diferenciables y de excepción: en uno se da la inaplicación del procedimiento ordinario de audiencia, lo cual siempre es especial o excepcional, y en otro se daría la sustitución del mismo procedimiento por la información pública, en cuyo caso la sustitución no sería imperativa sino discrecional. g) En el evento de aplicarse el procedimiento de información pública, el término "sometimiento" utilizado por la LGAP hace pensar que no solo sea para la simple información, sino también para la discusión activa y para recibir propuestas o pareceres ante las administraciones activas. h) En la aplicación 
hipotética de uno u otro procedimiento, sea el normal o sea el excepcional, el resultado de las consultas, en principio, no sería vinculante para las administraciones, sin que estas deban justificar sus pareceres opuestos, a pesar de la existencia de excelentes puntualizaciones u observaciones técnicas o de otra naturaleza. i) Por consiguiente, el resultado de la consulta o de la información puede ser engañoso, cuya verdad procedimental se transforma en una apariencia jurídica frente a administraciones con posturas predeterminadas e impuestas, a pesar de la posible existencia de criterios distintos y óptimos, sin que al final esto pareceres queden insertos en la disposición general propiamente dicha, ni aun incluso en su motivación. La consulta -insisto- en principio se traduciría en una mampara que esconde la tenebrosa burla, sin efecto sustancial alguno en favor de la participación ciudadana, a pesar de que el proyecto reglamentario haya pedido $-\mathrm{y}$ no ya solo aconsejare- diversidad de criterios, sean de rango público, privado o mixto, para satisfacer en alguna medida principios elementales de democracia activa. De esta manera estaríamos ante un choque frontal entre democracia participativa y administración autocrática con refuerzo burocrático, lo que dolorosamente es práctica usual en los sistemas democráticos y republicanos. Frente a esta frustrante y comprobada realidad, a lo sumo nuestra LGAP dice en su artículo 362: "En la disposición general se han de consignar expresamente las anteriores que quedan total o parcialmente reformadas o derogadas". Suponemos, con buena lógica consecuente, que hay referencia al resultado de los pareceres sectoriales o no sectoriales, que deben consignarse en los reglamentos que puedan ser reformados o derogados de forma parcial o total.

De ello bien podríamos valernos para discutir la mejor o peor aplicación de la discrecionalidad administrativa, siguiéndose el parámetro común de esta y su control judicial, en debido cumplimiento con el ordenamiento jurídico-administrativo, escrito y no escrito. Quedaría, pues, en manos del juez si la determinación administrativa se engarza o no en los criterios de la técnica, la lógica, la ciencia, la justicia o la conveniencia, en estricta relación con la circunstancia objetiva del caso, con seguimiento de los elementos reglados (artículos 15,2 y 16 LGAP).

La omisión de la expresa incorporación de los distintos pareceres constituiría en principio vicio de la plena nulidad en doble perspectiva: tanto por la violación del ordenamiento cuya omisión podría cambiar el resultado final de la disposición reglamentaria, como por el ocultamiento de los criterios distintos a los de la Administración en perjuicio de la certeza contralora judicial frente al ejercicio de la potestad discrecional. Así, entonces, bien debiera exigírsele a la Administración la motivación completa para modificar, ignorar o derogar alguna parte del contenido reglamentario, a fin de evitar administraciones autoritarias sumidas en el exceso o desviación de poder. Y para ello serviría en nuestro medio el artículo 136 inciso e) de la LGAP, que exige de las administraciones, aunque en forma sucinta, la motivación de los fundamentos de los reglamentos y de los actos discrecionales de alcance general. 
Asimismo, se dice (ibid., inciso 2) que la motivación "podrá consistir en la referencia explícita o inequívoca a los motivos de la petición del administrado, o bien a propuestas, dictámenes o resoluciones previas que hayan determinado realmente la adopción del acto, a condición de que se acompañe su copia”.

Si el reglamento es un acto administrativo general de alcance normativo, son válidos, por exigibles y legales, todos y cada uno de los condicionamientos formales y esenciales del acto, lo cual es una nota positiva de su equiparación jurídica.

El término "podrá", utilizado en la LGAP, siguiéndose la jurisprudencia española para otros supuestos, no es tanto para identificar la potestad discrecional administrativa de aplicar o no la motivación en la disposición reglamentaria, sino que está relacionado en esencia con el ejercicio efectivo de la potestad-imperatividad (poder). No habría entonces escapatoria para la Administración: la motivación es un imperativo, sea en relación con los motivos de las peticiones o (y) propuestas, dictámenes y resoluciones.

En todo caso, y bajo la atmósfera discrecional, las administraciones quedan limitadas ante los derechos del particular frente a ellas, salvo texto legal en contrario (artículo 17 ibid.). En otros términos: hay un derecho de audiencia ciudadano (personas jurídicas) y administrativo, salvo mejor criterio discrecional motivado por otro interés público prevaleciente o por urgencia sobrevenida, en el lineamiento de la misma ley que impone límites y atribuciones tasadas en el uso de la potestad discrecional administrativa. Contexto también aplicable, una vez ejercitada esa discrecionalidad, a la consulta pública, tanto en su causa como en su efecto para seguir, reformar o rechazar los criterios expuestos por los administrados, extensible a otras administraciones, para así justificar en oportunidad y legalidad el resultado final reglamentario, dentro de los parámetros de la discrecionalidad.

Un último aspecto debemos deslindar entre uno y otro procedimiento, sea el procedimiento popular o el restringido, relacionado con la información para que la audiencia sea efectiva, o que, si no lo fuera, ello no sea imputable a una Administración Pública que ha actuado de buena fe. En ambos supuestos, entonces, debiera hacerse un llamado al público, con primacía de los medios de comunicación escrita, incluyéndose el avance informático y los diarios de circulación nacional. No con esto debemos desechar el uso simultáneo de la comunicación verbal, sobre todo cuando el proyecto reglamentario pueda quedar sujeto a la valoración popular. Las administraciones deben ser agentes de comunicación efectiva para que el procedimiento también lo sea y no exista así un vicio ulterior de plena nulidad, a falta de audiencia debida en favor de algún potencial afectado con la disposición reglamentaria, una vez eficaz.

En el supuesto de que la información pública se filtrara en la participación de las personas jurídicas (que debiera ser también para las personas físicas), públicas, mixtas o privadas, en 
relación de causa y efecto con el proyecto reglamentario. En la otra hipótesis, no se requiere del ligamen de afectación directo o indirecto con el proyecto, aun cuando pueda existir tal afectación. Lo anterior no es un problema de legitimación sino de participación popular o sectorial relacionado con un proyecto reglamentario, el cual no debe tenerse como un acto final, mucho menos firme y definitivo.

\section{B.3.iii Análisis consecuente del artículo 363 de la LGAP}

Dice el artículo 363: “1. Los proyectos que deban someterse a la aprobación del Consejo de Gobierno se remitirán con ocho días de antelación a los demás Ministros convocados, con el objeto de que le formulen las observaciones pertinentes. 2. En casos de urgencia, apreciada por el Consejo, podrá abreviarse u omitirse el trámite del párrafo anterior.”

Desdoblemos, como hemos venido haciendo, el citado numeral:

1. Existen proyectos reglamentarios que deben ser sometidos al Consejo de Gobierno; estos son aquellos internos o de organización para su funcionamiento en el marco de la LGAP (artículo 46).

2. Consiguientemente, el Consejo de Gobierno tiene la potestad de dictarse su reglamento de organización en el encuadre de la ley. Por esto encontramos una reglamentación que es autónoma, de organización o independiente que deberá regirse por los parámetros de una ley anterior, lo que llega a relacionarse con la naturaleza de los reglamentos ejecutivos.

3. Lo anterior nos conduce a la distinción entre reglamentos de organización y reglamentos ejecutivos en su doble vertiente: a) tanto unos como otros participan del contenido legal, sin que puedan contradecirlo, parcial o totalmente; b) en ambos casos existen expresos señalamientos temporales para las audiencias relacionadas con los proyectos reglamentarios: en unos es de ocho días hábiles y en otros es de diez días hábiles. La LGAP deja a la discrecionalidad administrativa, salvo texto legal expreso, la determinación temporal para la elaboración de los reglamentos de organización de los entes descentralizados y de aquellos proyectos de reglamentos ejecutivos de consulta popular.

4. Sin embargo, el tratamiento que hace la LGAP en su artículo 6, en aplicación de la jerarquía de las fuentes del ordenamiento jurídico administrativo, puede llevar a cierta confusión. En efecto, al ubicarse la jerarquía normativa reglamentaria, los incisos d) y e) del referido artículo 6 señalan: "d) Los decretos del Poder Ejecutivo que reglamentan las leyes, los de los Supremos Poderes en la materia de su competencia; e) Los demás reglamentos del Poder Ejecutivo, los estatutos y los reglamentos de los entes descentralizados...”. Por consiguiente, existen en la dinámica del Poder Ejecutivo dos grandes espacios reglamentarios: los reglamentos ejecutivos propiamente dichos y los demás reglamentos que, aun siendo 
del Poder Ejecutivo, recaen por exclusión interpretativa en los reglamentos de organización, autónomos o de servicio. En razón de lo anotado, el concepto "Poder Ejecutivo" mantiene en sentido estricto una aplicación equívoca. Ciertamente, ese Poder -insisto- está conformado por el Presidente y el respectivo Ministro del ramo (o los ramos). Tal sentido se adentra en la dimensión estrictamente administrativa, por lo que concluiríamos, a simple vistazo, que los reglamentos de organización de toda la Administración Central deben ser dictados por el Presidente y el respectivo Ministro del ramo, lo que acercaría profundamente los reglamentos de organización a los reglamentos ejecutivos, en razón del elemento subjetivo. Y habría una cierta contradicción, por restrictiva, con otro numeral de la misma LGAP. En efecto, dice al texto su artículo 103 inciso 1): "El jerarca o superior jerárquico supremo tendrá, además, la representación extrajudicial de la Administración Pública en su ramo y el poder de organizar esta mediante reglamentos autónomos, de organización y de servicio internos o externos, siempre que, en este último caso, la actividad regulada no implique el uso de potestades de imperio frente al administrado". Por lo tanto, se ha de suponer que el Ministro -jerarca supremo en su ámbito competencial- tiene potestad de reglamentar la organización interna de un órgano incardinado en la Administración Central, sin que sea, entonces, en sentido estricto, el Poder Ejecutivo. Así pues, creemos que ha habido una cierta identificación, aunque no sea óptima, de la Administración Central con el "Poder Ejecutivo"; escollo que podría superarse ante la necesaria separación de ambos, es decir, si entendemos "Poder Ejecutivo" como órgano fundamental del Estado y no ya como órgano administrativo en sentido estricto (Presidente y Ministro del ramo).

5. Se regula legalmente la potestad reglamentaria de organización de los entes descentralizados, los cuales tienen rango inferior a los reglamentos ejecutivos, que tienen su fuente originaria en la Constitución Política. Pero al igual que los reglamentos autónomos de la Administración Central, la potestad reglamentaria recae en los respectivos jerarcas, siendo así que los reglamentos autónomos de los entes descentralizados y los de la Administración Central ostentan el mismo rango en la pirámide normativa.

6. En términos generales, el derecho de audiencia procede frente a proyectos de reglamentos ejecutivos y no así de organización o servicio. Es factible, en todo caso, una cierta audiencia a los Ministros o Viceministros, en su defecto, para conocer del proyecto de los reglamentos de organización del Consejo de Gobierno. O bien, en situación extrema pero viable, podría el Presidente de la República, conjuntamente con el respectivo Ministro, avocarse al conocimiento de cualesquiera de las materias de su competencia (artículo 25, inciso 2, ibíd.), diríamos también reglamentaria.

Llegados a este punto de encuentro debemos agregar un nuevo elemento de reflexión: el derecho de audiencia procede de la Administración hacia afuera, no así de la Administración 
hacia adentro. Sobre todo cuando esta puede, mediante potestades reglamentarias, dictar disposiciones que afecten los derechos de los funcionarios públicos en la relación de servicio con la Administración, salvo texto legal en contrario.

Ahora bien, los funcionarios públicos, como tales, no pierden el conjunto de derechos constitucionales como ciudadanos copartícipes en la función pública, en todo aquello que sea válido y legalmente aplicable. Ello sucede, a manera de ejemplo, con el derecho de asociación o el disfrute de libertades o derechos que no contradigan los lineamientos de la legalidad administrativa, lo que supone un tratamiento de justicia distributiva, e incluso podrían adentrarse en el conjunto de derechos sociales, que, por expresa disposición constitucional, son irrenunciables. Sin embargo, compartimos la preocupación del profesor Parejo cuando expresa, en su monografía sobre el Estado Social y la Administración Pública, que "la construcción de la Administración Pública sobre la base de la participación, no ya procedimental, sino orgánica, descansa en un análisis erróneo y supone una propuesta equivocada". ${ }^{37}$

Creemos, entonces, que si bien es cierta y necesaria la participación ciudadana en la elaboración de los reglamentos ejecutivos, sería inconveniente la participación funcionarial en la elaboración de los reglamentos autónomos o de servicio, a no ser del reglamento de organización -para Costa Rica- del Consejo de Gobierno. La razón es simple: debe dejarse un cierto margen de aplicación discrecional a las administraciones para la autoorganización, conforme al ordenamiento jurídico y su dimensionamiento teleológico. De lo contrario, podría darse el nefasto efecto de la "democracia contra la democracia", por la excesiva proliferación participativa que pudiera convertir a las administraciones, incluso para su régimen interno, en víctimas de intereses corporativos o asociativos con plena capacidad para paralizar total o parcialmente un servicio público que debe ser eficiente y continuo, entre otros principios ya apuntados, a fin de incidir negativamente en la debida prestación de servicios esenciales para los ciudadanos, para su salud o para el desarrollo de la personalidad, entre otros de suprema jerarquía sustancial.

Las administraciones públicas podrín desembocar, con desfiguración de su realidad querida o tenida, en la triste confirmación del Estado corporativo regulado por intereses opuestos al interés público, claramente singularizados en personas físicas o jurídicas con intereses egoístas y calculados. Se rompería, entonces, el esquema de las administraciones como agentes de satisfacción de intereses superiores o altruistas, sin que, por ello, pueda violar los derechos y libertades ciudadanos. La falta de regulación proclive para la previa participación de audiencia en favor de los funcionarios públicos, ante la eventual afectación de sus derechos por alguna

37 Del autor, Estado Social y la Administración Pública. Madrid: Editorial Civitas, 1983, p. 110. 
disposición reglamentaria, no impide la debida aplicación impugnatoria y fiscalizadora por parte del ordenamiento jurídico en el Estado de Derecho. En efecto, un reglamento autónomo de servicio que afecte los derechos y libertades ciudadanos puede ser impugnado, además, por los funcionarios que no hayan participado en su procedimiento de elaboración, sea ante la jurisdicción constitucional o sea ante la jurisdicción contenciosa administrativa que permite la impugnación directa de las disposiciones reglamentarias en general, sin necesidad de actos de aplicación individual. De tal manera que no por ser funcionarios públicos quedan al margen de los derechos impugnatorios para satisfacer los derechos fundamentales de todos los ciudadanos.

Tres realidades pues se imponen en esta perspectiva de participación procedimental en la dinámica de la nulidad absoluta: a) la nulidad de pleno derecho a falta de audiencia cuando el ordenamiento jurídico lo imponga para los proyectos de reglamentos ejecutivos; b) la plena nulidad de los reglamentos de organización, por violación del ordenamiento jurídico, no por incumplimiento del procedimiento de audiencia, a falta de disposición expresa a su favor, sino por la violación o amenaza a las situaciones jurídicas ciudadanas que, refleja o derivadamente, permiten coadyuvar a la defensa del ordenamiento jurídico, sus valores y fines; c) la plena nulidad de los reglamentos ejecutivos que han cumplido con el trámite de audiencia en el plazo y forma legales, sin que su normativa se ajuste al ordenamiento jurídico.

\section{A MANERA DE SIMPLE CONCLUSIÓN}

Mucho se puede agregar al derecho de participación ciudadana cuando la democracia no es vana ni engañosa, sino organismo compartido en sociedad. Demasiados aspectos de forma y sustancia quedan por comentar, sin que la temática esté agotada sino apenas iniciada con el lenguaje reformista y con la aplicación del método comparativo. Efectivamente, nuestra Constitución Política debiera colocarse en esa renovación y agudización de su letra y espíritu tanto en razón de reformas materiales y puntuales, como por la permanente adaptación de su normativa por la jurisprudencia constitucional en favor de los valores del sistema democrático, social y de Derecho. Recientes constituciones mantienen disposiciones jurídicas merecedoras del reconocimiento universal. Entre ellas están las de España, Suecia, Portugal, Colombia, Paraguay y Argentina.

En efecto, la Constitución sueca posibilita que en la preparación de sus asuntos el Gobierno otorgue "oportunidad a cualesquiera asociaciones e individuos, en la medida en que sea preciso, para que puedan exponer su parecer" (artículo 2 del capítulo 7), y establece la reserva de ley para todas aquellas funciones administrativas en el ejercicio de la potestad de imperio, sin lo cual se puede encomendar funciones administrativas "a sociedades, asociaciones, comunidades o fundaciones" (artículos 6 y 2 de los capítulos 11 y 7 respectivamente).

La Constitución de Portugal consagra que "la administración Pública será estructurada de tal modo que se aproximen los servicios a la población, se asegure la participación de los 
administrados en la gestión efectiva de los mismos, especialmente a través de las organizaciones populares de base o de otras formas de representación democrática y se evite la burocratización" (artículo 228).

Quizás la de mayor avanzada sea la Constitución de Colombia, para lo cual destacaré algunos preceptos que inciden de forma expresa y directa en el trasfondo de la democracia participativa, con la interacción del Estado y la sociedad. Dice: "Son fines esenciales del Estado... facilitar la participación de todos en las decisiones que los afectan y en la vida económica, política, administrativa y cultural de la Nación..." (artículo 2); "Todo ciudadano tiene derecho a participar en la conformación, ejercicio y control del poder político. Para hacer efectivo ese derecho puede: ... 2. Tomar parte en elecciones, plebiscitos, referendos, consultas populares, y otras formas de participación democrática... 6 . Interponer acciones públicas en defensa de la Constitución y de la ley..." (Artículo 40, incisos indicados.); "Son mecanismos de participación del pueblo en ejercicio de su soberanía: el voto, el plebiscito, el referendo, la consulta popular, el cabildo abierto, la iniciativa legislativa y la revocatoria del mandato. La ley los reglamentará..." (artículo 103); "Un número de ciudadanos equivalentes a la décima parte del censo electoral, podrá solicitar ante la organización electoral la convocación de un referendo para la derogatoria de una ley. La ley quedará derogada si así lo determina la mitad más uno de los votantes que concurran al acto de consulta, siempre y cuando participe en este una cuarta parte de los ciudadanos que componen el censo electoral..." (artículo 170). Agrega: "A la Corte Constitucional se le confía la guarda de la integridad y supremacía de la Constitución... cumplirá las siguientes funciones: ... 3. Decidir sobre la constitucionalidad de los referendos sobre leyes y de las consultas populares y plebiscitos del orden nacional. Estos últimos solo por vicios de procedimiento en su convocatoria y realización...” (artículo 241.3); "La Constitución Política podrá ser reformada por el Congreso, o por una Asamblea Constituyente o por el pueblo mediante referendo" (artículo 374).

No menos interesante es la Constitución de la República del Paraguay cuando incluye, sin tanta restricción, el referendo legislativo, decidido por ley, el cual podrá ser o no vinculante (artículo 121); la iniciativa popular para que los electores puedan proponer directamente al Congreso proyectos de ley (artículo 123); la expresa legitimación objetiva a toda persona para reclamar "a las autoridades públicas medidas para la defensa del ambiente, de la integridad del hábitat, de la salubridad pública, del acervo cultural nacional, de los intereses del consumidor y de otros que, por su naturaleza jurídica, pertenezcan a la comunidad y hagan relación con la calidad de vida y con el patrimonio colectivo" (artículo 38).

La Constitución de Argentina incorpora el derecho de iniciativa popular para la presentación de proyectos de ley en la Cámara de Diputados (artículo 38); también se da la consulta popular a instancia de la misma Cámara de Diputados, en relación con proyectos de 
ley que el Congreso someta a tal consulta, siendo así que el voto afirmativo lo convertiría en ley y su promulgación sería de efecto inmediato (artículo 40).

La Constitución de Costa Rica, como se ha insistido, comienza a retomar los surcos de la participación popular, sin una regulación óptima a nivel constitucional. Por su parte, la LGAP incluyó la participación ciudadana, pero aún requiere de mayores alcances cualitativos e igualitarios. Entre los dichos, otro por señalar, a saber: la obligada procedencia de la consulta popular para reglamentos que desarrollen leyes cuyo contenido inequívocamente esté ligado a los derechos fundamentales. La complementación de esas disposiciones reglamentarias debiera ser sometida a la información pública, conjuntamente con otras materias que, en criterio discrecional administrativo, puedan ser objeto de confirmación participativa.

Sin duda alguna, el conocimiento es acumulativo con fundamento en la experiencia propia y ajena. Y sobre este suelo debemos zarpar en la conquista de distintas formas de participación popular. Efectivamente, los Tribunales Constitucionales u órganos encargados de dictar justicia constitucional (como el caso de la Sala Cuarta en nuestro medio) debieran tener la causa material de constituciones modernas con excelsos criterios técnicos y expresiones claras y precisas, que en modo alguno sean de difícil comprensión ni memorización ciudadanos, sino que, al contrario, constituyan textos de fácil acceso popular, en lo que el pragmatismo y utilitarismo anglosajón tienen mucho que enseñar.

El Estado y la sociedad han dejado de ser en este siglo XXI dos realidades irreconciliables, enemigas o distanciadas en puntos extremadamente antitéticos. El Estado como Leviatán, al estilo de Hobbes o a la manera del monstruo frío de Nietzsche, no puede tener cabida en la democracia que busca desempolvar sus instituciones a favor de los despachos abiertos, soleados y ventilados, por la transparencia de actuación, la rendición de cuentas y la participación y fiscalización ciudadanas, en lo que también juega un rol de primera importancia el control a través de los medios de comunicación, en aras de la libertad de petición e información frente a conductas activas o pasivas adentradas en la esfera pública.

La autocracia, en cualquiera de sus manifestaciones, sea directa o indirectamente, sea manifiesta o solapadamente, aun en democracia, debe ser extirpada por los medios dentro del Estado, para no llegar a los medios sin el Estado o contra el Estado o sobre este. La fenecida y sufrida República de Weimar nos da el antídoto inicial frente a la desconfianza ciudadana, para evitar tragedias republicanas con su largo historial de dolor por la permanente lucha de la libertad y la dignidad. De lo contrario, seríamos parte del principio del fin, cuando debiéramos imponer el fin del principio. 


\section{REFERENCIAS}

- Belmonte, José. La Constitución. Texto y contexto. Editorial Prensa Española, 1979.

- Delaunay. Les feuillets du temps vole. Paris.

- Ebenstein, William. El totalitarismo. Buenos Aires: Paidós, 1965.

- Häberle, P. Libertad, igualdad, fraternidad. 1789 como historia, actualidad y futuro del Estado constitucional. Madrid: Mínima Trotta, 1998.

- "La libertad constitucional de petición y su efectiva protección jurisdiccional en la vía de Amparo". Revista Lustitia. No. 53, mayo 1991.

- Leibholz, G. "El Tribunal Constitucional de la República Federal de Alemania y el problema de la apreciación judicial de la política”, en: REP, 1966.

- Pizzorusso, Alessandro. Lecciones de Derecho Constitucional. Madrid: Centro de Estudios Constitucionales, 1984.

- "Problemas constitucionales del Estado social", en: El Estado social. Madrid: Centro de Estudios Constitucionales, 1986.

- Santamaría, Pastor. Apuntes de Derecho Administrativo. Madrid, 1987.

- Schmitt, Carl. "Der Rechtsstaat", en: Nationalsocialistisches Handbuch für Recht und Gesetzgebung. München, 1935.

- Stern, Klaus. Derecho del Estado de la República Federal Alemana. Madrid: Centro de Estudios Constitucionales, 1987.

- Weiss, Paul. "Common Sense and Beyond”, en: S. Hook, Determinism and Freedom in the Age of Modern Science. New York: Coliers, 1961. 